\title{
Does climate change make foodgrain yields more unpredictable? Evidence from India
}

\author{
Saumya Verma \\ Email: saumya@econdse.org \\ Lady Shri Ram College \\ University of Delhi \\ Shreekant Gupta \\ Email: sgupta@econdse.org \\ Department of Economics \\ Delhi School of Economics \\ Partha Sen \\ Email: partha@econdse.org \\ Centre for Development Economics \\ Delhi School of Economics \\ \& \\ CESifo
}

\section{Working Paper No. 305}

http://cdedse.org/wp-content/uploads/2020/02/Working-Paper-305.pdf

DELHI SCHOOL OF

ECONOMICSDELHI 110007 


\title{
Does climate change make foodgrain yields more unpredictable?
}

\section{Evidence from India}

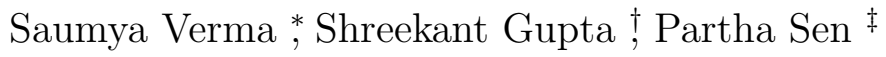

\begin{abstract}
How would climate change affect India's agriculture which accounts for sixty percent of employment? We study the impact of climate change on the level and variability of yields of rice (India's major food crop) and two key millet crops (sorghum and pearl millet), using an all India district level panel dataset from 1966-2011. A stochastic production function is estimated with exogenous climate anomalies. We find that climate change adversely affects both the level and variability of crop yields - rice yields are reduced by rainfall extremes whereas extremely high temperatures make yields of all three crops highly variable with the biggest impact on millets.
\end{abstract}

Keywords : agriculture, climate change, foodgrain yields, India, millets, rice, stochastic production function.

JEL Classification : Q54, O13, D24

We are grateful to Kamaljit Ray and Priyanka Singh of the India Meteorological Department for the weather data used in the study. This paper has benefited greatly from comments by Gaurav Arora, Yoshihisa Godo, Madhu Khanna, Takashi Kurosaki and J.V. Meenakshi, and from participants in seminars at the Institute for Economic Research, Hitotsubashi University, Koc University, Ifo Institute for Economic Research, Technical University of Munich, Nanyang Technological University, North Eastern Economic Association, Assam, Indian Statistical Institute and South Asian University, Delhi. We would like to thank all of them. All remaining errors are our own.

\footnotetext{
*Lady Shri Ram College, University of Delhi, Delhi, 110024, India. Email: saumya@econdse.org

${ }^{\dagger}$ Department of Economics, Delhi School of Economics, University of Delhi, Delhi, 110007, India. Email: sgupta@econdse.org

${ }^{\ddagger}$ Centre for Development Economics, Delhi School of Economics, University of Delhi, Delhi, 110007, India and CESifo, Munich, Germany. Email: partha@econdse.org
} 


\section{Introduction}

The impact of climate change on agriculture especially in developing countries has spawned a vast literature and rightly so. For one, the effect of climate is most directly felt on agriculture compared to other sectors. Second, this sector is particularly salient for developing countries which are going to be most hard hit by climate change (IPCC 2014). Even for a lower middle income country such as India, agriculture still accounts for about 58 percent of the workforce (Kadiyala et al. 2014) and 60 percent of the population depends on agriculture directly or indirectly. Within the overall context of climate change, its role in increasing variability of future crop yields, especially that of foodgrains, has received considerable attention. ${ }^{1} \mathrm{~A}$ large number of studies have estimated a stochastic production function (SPF) (Just and Pope 1978,1979$)$ to measure the impact of weather on the mean and variance of crop yields. ${ }^{2}$ These studies cut across developed and developing countries and have been conducted for various food and non-food crops. Some examples are Chen, McCarl, and Schimmelpfennig (2004); Isik and Devadoss (2006); McCarl, Villavicencio, and Wu (2008); Kim and Pang (2009); Barnwal and Kotani (2010); Cabas, Weersink and Olale (2010), Palanisami et al. (2011), Boubacar (2012), Guttormsen and Roll (2013), Hasanthika et al. (2013), Holst et al. (2013), Poudel and Kotani (2013), Poudel, Chen and Huang (2014), Sarker et al. (2014), Arumugam et al. (2015), Kabir et al. (2015), Kumar, Sharma and Ambrammal (2015), Singh, Sharma and Singh (2016), Sarker et al. (2017), Arshad et al. (2016), Haile et al.

\footnotetext{
${ }^{1}$ Concern about variability of grain yields as a source of instability in food production predates climate concerns (Anderson and Hazell 1989). It has been recognized that production risk in agriculture increases income risk especially in developing countries where there are a large number of small farmers (Anderson and Hazell 1989). It also increases instability of national and world food supplies (op. cit.). Climate change can further exacerbate production risk in agriculture. An early study modeling impacts of climate impacts using a SPF argues "(U)ncertainties in weather create risky environments for crop production, farming systems, food supply as well as securities." (Chen and Chang 2005, p. 503)

${ }^{2} \mathrm{~A}$ parallel and longstanding literature uses stochastic weather generators to derive climate scenarios which are then combined with agricultural crop models (for example the CERES-Wheat model) to simulate effects on the mean and variance of crop yields (Mearns et al. 1997, Hoogenboom 2000, Torriani et al. 2007, Xiong et al. 2008).
} 
(2017), Mahmood et al. (2019) and Saei et al. (2019). ${ }^{3}$

In this paper we use the Just-Pope SPF to estimate the impact of climate change on the mean and variance of yields of food crops in India. Our work differs and builds upon previous research in several important ways. First, unlike previous studies our focus is not only on weather, per se, but also on climate. Thus, we extend the existing literature by calculating and using rainfall and temperature anomalies (deviations from the long period average (LPA) or historical mean) as a measure of climate change/shock instead of focusing only on annual/seasonal rainfall and average annual/seasonal temperature (which are essentially weather variables). McCarl, Villavicencio, and $\mathrm{Wu}$ (2008) use mean and standard deviation of temperature during the growing season but this is not a measure of climate change. We also allow for asymmetric climate effects by including negative and positive anomalies separately in the estimation. ${ }^{4}$ This is also helpful in interpreting the sign on the anomaly coefficient unlike the case where the variable encompasses both negative and positive deviations.

The second difference is we use a long panel spanning almost half a century (1966-2011). This is useful since climate change unfolds over long timescales. The only panels longer than ours are Haile et al. (2017) and Isik and Devadoss (2006). The former is a country level panel which constrains them to aggregate/average weather variables for an entire country. Isik and Devadoss (op. cit.) have panels of 63, 53 and 27 years, respectively for the crops

\footnotetext{
${ }^{3}$ This extensive (but not exhaustive) list modifies the claim of one of the earliest Just-Pope SPF studies: "Many studies have been done regarding the effect on the mean of such distributions but few have addressed the effect on variance." (Chen, McCarl, and Schimmelpfennig 2004, p. 239)

${ }^{4}$ To the best of our knowledge only three Just-Pope SPF studies use climate anomalies two of which do not use panel data and are cross-sectional. Mahmood et al. (2019) calculate anomaly for temperature but not for rainfall. They find the (positive) temperature anomaly is highly significant with a strong negative impact on the mean yield of wheat in Pakistan. Arshad et al. (2016) is also for Pakistan. They calculate both temperature and rainfall anomaly. The temperature anomaly affected mean wheat yield negatively and yield variability positively (i.e., increased production risk). Rainfall anomaly showed no significant effect on either mean wheat yield or variability. As stated earlier while both studies estimate a Just-Pope SPF, they are limited to a cross-section across a small sample (400 and 240 farmers, respectively) at one point in time and therefore of limited relevance for our purpose. The only panel data study that uses climate anomalies is Holst et al. (2013) for Chinese provinces bifurcated into two regions. Other than a negative and significant impact of the rainfall anomaly on mean yield in one region, neither of the two anomalies have any impact on mean or variance of yields. Unlike our analysis Holst et al. (op. cit.) do not account for the potentially asymmetric impact of negative and positive anomalies by entering them separately in the SPF.
} 
they study but only for 3 or 4 provinces within Idaho. With a large $T$ and very small $N$, fixed effects estimation becomes difficult (Wooldridge 2012). All other studies have shorter panels than ours, some as small as a couple of decades making it difficult to capture climate change.

Thirdly, our analysis is at the granular level of districts for all of India. ${ }^{5}$ For a country of sub-continental proportions (India is the seventh largest country in the world with NorthSouth and East-West extent of approximately 3,000 kilometres each) the impact of climate change is markedly different across geographies. Analysis using state level panel data for India (Singh, Sharma and Singh 2016) requires representing climate/weather variables with a single number for large geographies (some states are larger than countries in Europe). This issue of aggregation is even more problematic for studies that use country level panels (Boubacar 2012 and Haile et al. 2017). With regard to the extent of geographical coverage, our analysis covers all of India. In contrast other studies for India are state specific or only cover a few districts and are difficult to generalise (Barnwal and Kotani 2010, Palanisami et al. 2011 and Arumugam et al. 2015). This is also true for studies in other countriesHasanthika et al. (2013) consider only 6 districts in Sri Lanka.

As a final point, our study includes non-climate variables in the SPF, namely, cropped area, irrigation, fertilizer and high yielding variety (HYV) seeds. With the exception of few studies $^{6}$ all others only use rainfall and temperature (defined in a variety of ways) in the estimation of the SPF. It is however important to control for inputs when looking at the impact of climate/weather on mean yields and also because inputs them may ameliorate or exacerbate production risk (Guttormsen and Roll 2013, Rosegrant and Roumasset 1985, Roumasset et al.1989, Ramaswami 1992, Di Falco, Chavas and Smale 2006).

The rest of the paper is organized as follows. In the next section trends and regional

\footnotetext{
${ }^{5} \mathrm{~A}$ district is the primary administrative and economic sub-division of Indian states. As of 2016 there were a total of 707 districts up from 640 in the 2011 Census and 339 in the 1961 Census. The average area of a district is approximately $4,000 \mathrm{sq} \cdot \mathrm{km}$.

${ }^{6}$ These are Cabas et al. (2010), Hasanthika et al. (2013), Holst et al. (2013), Singh, Sharma and Singh (2016) and Haile et al (2017).
} 
variation in climate variables (rainfall and temperature) for India are discussed, followed by a description of the importance of rice and millets for the Indian economy, and the crucial role climate variables play in their production. This is followed by a description of the data, methodology, discussion of results and concluding remarks.

\section{Climate Change and Agriculture in India}

\section{Trends and regional variation in rainfall and temperature}

Climatic conditions in India are determined mainly by summer or south west monsoon ${ }^{7}$ and by the country's physiological features such as the western and eastern Ghats, the central plateau and the Himalayas. The summer monsoon and the rains that it brings are a major weather phenomenon in the Indian subcontinent and deeply influences lives of its inhabitants. It is a four-month period (June-September) when massive convective thunderstorms dominate India's weather, and is the Earth's most productive wet season (Collier and Webb 2002). As we elaborate later the temporal and spatial distribution of precipitation (rainfall) accompanying the monsoon is particularly important for agriculture.

The summer monsoon is also the most economically important weather pattern to the extent a recent Indian Finance Minister (Pranab Mukherjee) called it the real finance minister. $^{8}$ More recently, the Governor of India's central bank (Reserve Bank of India or RBI) was also quoted as saying "(A)nd most importantly we also chase monsoon like millions of farmers across the country." So, the monsoon outlook, the monsoon performance is going to be the important factor in determining RBI policy in the next three months. ${ }^{9}$

Figure A.1 (Cagliarini and Rush 2011) shows the tight relationship between monsoon and agricultural output. This is not surprising. Even 70 years after independence about

\footnotetext{
${ }^{7}$ In the discussion below we sometimes use the term monsoon to refer to summer monsoon rainfall since the winter monsoon is relatively unimportant.

8 "India cheers as monsoon arrives; hope of better farm output raised." Hindustan Times May 31, 2010.

9 "Monsoon outlook to determine policy actions: Subbarao." Economic Times June 7, 2013.
} 
60 percent of the total farming area in the country remains rainfed without access to either irrigation or perennial snow fed rivers. Rainfed agriculture contributes 44 percent of total food grain production of the country and produces 75 percent of pulses and more than 90 percent of millets and groundnut. Rainfed (i.e., arid and semi-arid) regions provide livelihood to nearly 50 percent of total rural workforce and sustain 60 percent of cattle population of the country (MNI 2009).

All India summer monsoon rainfall from 1871-2009 shows only a slight negative trend (0.4 mm per year). ${ }^{10}$ There is, however, considerable inter-annual variability during this period, which is evident from the literature. These inter-annual variations cause droughts and floods in many parts of the country and their persistence on decadal time scales leads to long-term climatic changes. Since 1970, however there has been a decreasing trend in monsoon rainfall largely due to a climate induced weakening of the Southern Oscillation (El Nino effect)(Naidu et al. 2009). ${ }^{11}$

There is also significant spatial variation in rainfall as would be expected in a country of this size, with amounts ranging anywhere from $2828 \mathrm{~mm}$ (in Kerala) to $441 \mathrm{~mm}$ (in Rajasthan) annually (Gilmont et al. 2018). It is quite possible for one part of the country to experience excess rainfall and another deficient rainfall (respectively, greater or less than 20 percent of normal) at the same time. ${ }^{12}$ In addition in many places in India there is an increasing trend in 1-day extreme rainfall events during the period 1901-2000 (Sen Roy and Balling Jr 2004) and 1951-2007 (GoI 2010) ${ }^{13}$ These aspects are particularly significant for agriculture where it is the variability of rainfall on shorter time scale that has devastating impacts - intense heavy rainfall leads to flooding; breaks in the monsoon of a week or

\footnotetext{
${ }^{10}$ Mean rainfall over this period is $848 \mathrm{~mm}$ with standard deviation of $83 \mathrm{~mm}$.

11 "In the global warming era (1970 - 2005), 19 out of 30 meteorological subdivisions showed negative tendencies in summer monsoon rainfall. This decrease in summer monsoon rainfall is associated with a weakening of the Southern Oscillation and relaxation of the meridional temperature gradient over the Indian Ocean." (op. cit. p.1) The Indian Meteorological Department (IMD) classifies India into 36 meteorological subdivisions and reports rainfall data for each separately. This study considered 30 of these subdivisions.

${ }^{12}$ Simultaneous floods and droughts across meteorological subdivisions are known to happen.

${ }^{13}$ In the monsoon trough region more than $50 \mathrm{~cm}$ rainfall has been recorded in one day (GoI 2010).
} 
more lead to water shortage and agricultural drought. In 2002 for example, a break in the monsoon rains saw July receiving only about 50 percent of its normal rainfall, leading to cuts in agricultural output and declining GDP.

For India as a whole, mean annual temperature shows a significant warming trend of 0.60 degrees Celsius per 100 years during the period 1901-2018 (GoI 2018). ${ }^{14}{ }^{15}$ More important, warming has accelerated in recent times. The past decade was the warmest on record with anomalies of 0.38 degrees Celsius above average. In fact, annual mean temperature in the year 2018 was 0.40 degrees Celsius above the 1971-2000 average, making it the sixth warmest year on record since record keeping began in 1901 (GoI 2018). ${ }^{16}$ In passing we also note India recorded it's hottest day ever on May 19, 2016 when a town in western India (Phalodi) recorded 51 degrees Celsius (123.8 degrees F). The previous record was 50.6 degrees Celsius set in 1956.

Projections for climate in the medium-run for India seem to indicate it will be warmer and wetter but with significant regional variation. Overall there will be (i) an increase in average surface temperature by 2-4 degrees Celsius, (ii) changes in the distribution of rainfall (inter temporal and spatial) during both monsoon and non-monsoon months, (iii) decrease in the number of rainy days by more than 15 days, (iv) an increase in the intensity of rainfall by 1-4 mm/day, and (v) an increase in the frequency and intensity of cyclonic storms (Ranuzzi and Srivastava 2012).

As with rainfall, for a country of subcontinental proportions aggregate temperature

\footnotetext{
${ }^{14}$ The increase in mean annual temperature was accompanied by a significantly higher rate of increase in maximum (daytime) temperature (1 degrees Celsius per 100 years) and a relatively lower rate of increase (0.20 degrees Celsius per 100 years) in minimum (nighttime) temperature over the same reference period 1901-2018. However, there has been a reversal in this in recent years and nighttime temperatures have increased more than daytime temperatures, suggesting the possible role of moisture and the greenhouse gases (Rohini, Rajeevan, and Srivastava 2016). This has significant implications for rice yields in particular (Peng et al. 2004).

${ }^{15}$ We also note all four major Indian seasons as classified by IMD, namely, summer/pre-monsoon, monsoon, post-monsoon and winter contribute to this trend. But the increase in winter and post-monsoon temperatures is most marked - by 0.80 and 0.82 degrees Celsius, respectively over the last hundred years (GoI 2010).

${ }^{16} 2018$ was not an outlier. 11 of the 15 warmest years ever recorded were from the recent past 15 years (2004-2018) (GoI 2018).
} 
trends can be misleading. An analysis of the spatial trend in the rate of increase of mean annual temperature (degrees Celsius per 100 years) for the period 1901-2016 shows that most parts of the country have become warmer (significant positive trends) except some parts of Gujarat and Bihar which have become cooler (but then other parts of Gujarat have warmed at the rate of 1.5 degrees Celsius per 100 years). Within the context of an overall warmer India contour lines show differential warming across the country ranging from 0 to 1.5 degrees Celsius per 100 years (GoI 2016a).

A particularly pernicious manifestation of this warming is greater likelihood of extreme temperatures which in turn could lead to heat waves that devastate crops and rural livelihoods. ${ }^{17}$ In fact, the frequency, duration and intensity of heat waves in India has increased (Rohini, Rajeevan, and Srivastava 2016). ${ }^{18}$

To sum up, it makes little sense to talk about climate for India as a whole - both rainfall and temperature show considerable variation along various dimensions - annually, by season and even daily, across space for different regions and even within regions. For this reason our climate dataset is at the district level (535 districts as in 2011). It comprises daily rainfall and temperature thus capturing both temporal and spatial variability at a granular level. ${ }^{19}$

\section{Rice and millets in India}

As mentioned earlier, rice is the most important (and ubiquitous) food crop in India in terms of area and production. The production of rice has increased five fold from 21 million tons in 1950 to 105 million tons in 2014. In India rice is grown under widely varying conditions

\footnotetext{
${ }^{17}$ Heat waves are anomalous episodes with extremely high surface air temperatures, lasting for several days with serious consequences. Over India, in the past, heat waves have caused more deaths than any other natural hazard (Rohini, Rajeevan, and Srivastava 2016)

18 "Farmer suicides soar in India as deadly heatwave hits 51 degrees Celsius." The Independent May 20, 2016.

${ }^{19}$ Daily gridded rainfall data at $0.25 \times 0.25$ and temperature data at $0.5 \times 0.5$ degree resolution from IMD for the time period 1960-2017 was used to calculate district level daily rainfall and temperature.
} 
of altitude and climate. The crop requires sufficient water for growth. ${ }^{20}$ In the absence of irrigation, cumulative rainfall required for growth is between 100-200 cm. Though about 60 percent of the area under rice is irrigated, rainfall can play a complementary role here as well.

Rice growing seasons vary in different parts of the country, depending upon temperature, rainfall, soil types, water availability and other climatic conditions. In eastern and southern regions of the country, mean temperature is favourable for rice cultivation throughout the year. Hence, two or three crops of rice are grown in a year in the eastern and southern states. In the northern and western parts of the country, where winter temperature is fairly low, only one crop of rice is grown during the month from May to November.

In India, rice is grown in three seasons - autumn (pre-kharif), winter (kharif) and summer (rabi). Moreover, cropping seasons vary slightly from state to state according to weather conditions and rainfall patterns. The crop is mainly grown during winter or kharif season. ${ }^{21}$ Rice is a thermal sensitive crop. Increase in temperature affects crop growth with adverse effects on grain quality (Barnabas, Jager, and Feher 2008). Among millets, pearl millet (bajra) is the most widely grown type of millet followed by sorghum (jowar $)^{22}$ Pearl millet is grown as a single season (kharif) rainfed crop, predominantly in the dry north western states of Gujarat and Rajasthan on marginal and unirrigated lands. Sorghum is cultivated during both kharif (as a rainfed crop) and rabi (under residual soil moisture) seasons. It is grown largely in the arid and semi-arid regions of central India. Both crops grow under varied climatic conditions and have limited input requirements such as fertilizer and water - less then a tenth of area under either crop is irrigated compared to 60 percent for rice and and 94 percent for wheat (GoI 2016b). The other advantages of these crops are that they are drought tolerant, short to medium duration, resistant to pests and diseases

\footnotetext{
${ }^{20} \mathrm{On}$ average it takes 1,432 litres of water to produce $1 \mathrm{~kg}$ of rice in an irrigated lowland production system (IRRI http://www.knowledgebank.irri.org/step-by-step-production/growth/water-management).

${ }^{21}$ As can be noted sowing and transplanting of winter rice is during the summer monsoon (June- September).

${ }^{22}$ Sorghum is actually a cereal whereas millet (including pearl millet) is any of a group of grasses. In both cases the grains are used to make flour and as cattle feed. The former is sometimes known as great millet.
} 
(i.e., fewer pesticides) and require less labour (e.g., unlike rice) (Nagaraj et al. 2013).

Millets are specially important for the poor and vulnerable in India for a number of reasons. $^{23}$ As mentioned earlier they play a major role in smallholder farming systems in the arid and semi-arid (rainfed) regions of the country that comprise 60 percent of total cultivated land. In particular, millets are mainly grown by small and marginal farmers, that is, those with farm size less than 5 hectares (Swaminaidu et al. 2015). Millets also form the staple diet of a majority of poor smallholders and poor consumers in regions where they are grown. They are the richest sources of nutrition, especially iron, calcium, and zinc, among cereals and can provide all the nutrients at least cost to the poor compared to wheat and rice (Rao et al. 2006). The crop residue of sorghum and pearl millet forms an important component of feed for livestock (Rao and Hall 2003).

All this notwithstanding both crops have lost ground - between 1970-71 and 2013-14 7 million hectares of sorghum and 4 million hectares of pearl millet were diverted to other crops (GoI 2016b). ${ }^{24}$

\section{Data}

Annual data on agricultural inputs and outputs for 311 districts of India from 1966-2011 has been procured from the International Crops Research Institute for the Semi-Arid Tropics (ICRISAT) Village Dynamics in South Asia (VDSA) Meso Apportioned database (ICRISATICAR-IRRI 2015). The data base is a compilation of data collected by Directorate of Eco-

\footnotetext{
${ }^{23}$ Sorghum is an important staple of low- and middle-income consumers in regions where it is grown. For example, in rural areas of central Maharashtra, per capita annual consumption of sorghum is around $60 \mathrm{~kg}$, accounting for almost half (48 percent) of per capita consumption of all cereals. Similarly, in the major pearl millet-producing regions, per capita consumption is highest (69 kg/year) in rural Rajasthan and in the dry areas of Gujarat ( $59 \mathrm{~kg} /$ year). In these two regions, pearl millet accounts for more than 50 percent of cereal consumption, contributing about 20 percent to 40 percent of the total energy and protein intake (Rao et al. 2006, Nagaraj et al. 2013). Ironically, at the all-India level annual per capita consumption of sorghum and pearl millet has declined sharply over the last forty years to merely $2-3 \mathrm{~kg}$ at present. Some of the reasons are official policies that subsidize consumption of wheat and rice and that millets are considered an inferior good and suffer as incomes rise (Rao et al. 2006, Basavaraj et al. 2010, Chand 2007).

${ }^{24}$ This coincided with the "green revolution" in India that witnessed dramatic increases in yields of wheat (and to a lesser extent rice) on the back of hybrid seeds, subsidized water and fertilizer and price supports.
} 
nomics and Statistics of the respective state governments. Variables relevant for our study are crop area and production and agricultural inputs, i.e., fertilizers, irrigated area and area under high yielding variety seeds (where data on the latter two variables is available by crop).

Crop yield was obtained using data on crop production and crop area, (where crop yield is crop production per unit area). Estimates of crop area and production account for multiple cropping indicative of crop sown throughout the year. Crop area and production are reported in '000 hectares and '000 tonnes respectively, hence the dependent variable is measured in tonnes per hectare.

Fertilizer is the aggregate consumption of nitrogen, phosphate and potash used for production, measured in tonnes. However, data on fertilizers used is not available by crop. Crop specific fertilizer consumption was obtained by pro rating total consumption by proportion of area under the crop (i.e. district level crop area as a proportion of gross cropped area), which is expressed per hectare. Similarly, data on irrigated crop area and area under high yielding variety seeds was expressed per hectare.

We find evidence of significant increases in area under irrigation and high yielding variety seeds, particularly for rice, leading to more than 100 percent increase in rice yields from 1 ton/ha to 2.5 ton/ha during 1966-2011 (see Figure A.2). Variation in climatic conditions across crops is evident from Figures A.3 and A.4 respectively, with rice grown in the districts with higher rainfall and lower annual average temperature. Millets on the other hand, are grown in the lower rainfall high temperature districts. It can be seen from Figure A.5 that at the all India level, there have been considerable deviations in rainfall (from long period average) during 1966-2011, with significant rainfall deficit during the last decade, where annual rainfall is observed to be as low as 20 percent below long period average. This can have serious implications for Indian economy given the importance of monsoon rainfall in agricultural production. Trends in all India annual average temperature also point to significant inter annual variations in temperature. Even more harmful is the increasingly higher and positive deviation of annual average temperature (from the long period average) with deviations as high as 3 percent during 2000-2011, indicating significant warming in 
these years (see Figure A.6).

We use daily gridded rainfall and temperature data sets recently developed by India Meteorological Department (IMD) (Srivastava, Rajeevan, and Kshirsagar 2009; Rajeevan et al. 2005). Daily rainfall data at $0.25 \times 0.25$ degree latitude/longitude resolution and temperature data at 0.5 x 0.5 degree latitude/longitude resolution from 1960-2017 is used. To obtain district level estimates of rainfall and temperature an average of observations at grid points within the district boundary is taken. From the daily district level data on rainfall and temperature, annual rainfall is obtained by summation of daily rainfall values where as annual average temperature is the average of daily temperature values. Summary statistics for the variables of interest can be seen in Table 1 .

\section{Methodology}

Climate anomaly refers to the difference of annual weather observations from a climate normal (or long period average). ${ }^{25}$ Climate normal is usually calculated by averaging 30 or more years of data (Arguez and Vose 2011). ${ }^{26}$

If $x_{i t}$ denotes annual rainfall/temperature in district $i$ in year $t, \bar{x}_{i}$ and $\bar{\sigma}_{i}$ denote its mean and standard deviation, then climate anomaly $\left(C A_{i t}\right)$ is defined as : $C A_{i t}=x_{i t}-\bar{x}_{i}$ and standardized climate anomaly $\left(S C A_{i t}\right)$ as,

$S C A_{i t}=\frac{x_{i t}-\bar{x}_{i}}{\bar{\sigma}_{i}}$

To incorporate asymmetric response of crop yields to rainfall and temperature extremes, four anomaly variables were defined capturing significant deviations in rainfall and temperature from long period average. These anomaly variables have been defined following Indian Meteorological Department's definition of all India anomalies. ${ }^{27}$

Deviations of annual rainfall from long period average are considered 'normal' if

\footnotetext{
${ }^{25}$ https://www.ncdc.noaa.gov/monitoring-references/dyk/anomalies-vs-temperature

${ }^{26}$ More recently, climate anomalies have been used in the literature in a non environmental context as well (Call, Gray, and Jagger 2019).

27 "Met Glossary" Retrieved from http://www.imdpune.gov.in/Weather/Reports/glossary.pdf
} 


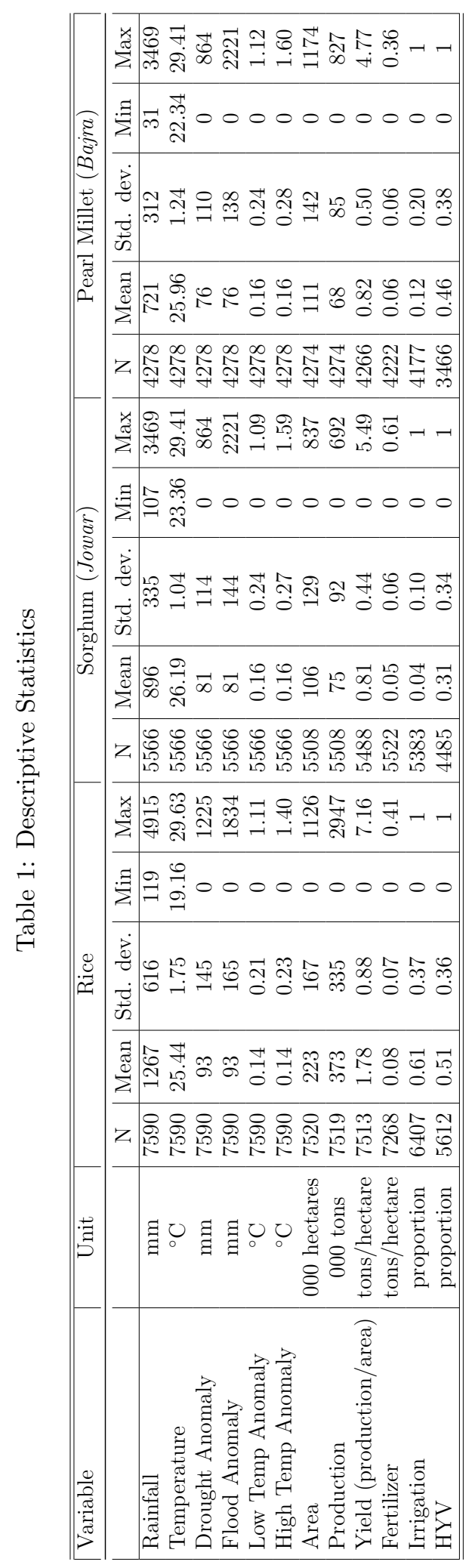


$x_{i t} \epsilon\left[\bar{x}_{i} \pm 0.04 * \bar{x}_{i}\right]$. i.e., deviations in annual rainfall within \pm 4 percent of long period average are considered 'normal', where as any deviation in rainfall beyond 4 percent of LPA describes extreme rainfall conditions.

If $R A_{i t}$ and $T A_{i t}$ denote rainfall and temperature anomalies respectively, anomalies capturing rainfall extremes are defined as :

Drought Anomaly $_{i t}= \begin{cases}R A_{i t} & \text { if rainfall } \\ 0 & \text { otherwise }\end{cases}$

Flood Anomaly $= \begin{cases}R A_{i t} & \text { if rainfall } \text { rit } \geq 1.04 * \bar{x}_{i} \\ 0 & \text { otherwise }\end{cases}$

For temperature anomalies, deviations of annual average temperature (from LPA) exceeding 0.10 degree Celsius ${ }^{28}$ represent extreme temperature conditions. Anomaly variables capturing temperature extremes are thus defined as:

Low Temp Anomaly $i t= \begin{cases}T A_{i t} & \text { if } T A_{i t} \leq-0.10 \\ 0 & \text { otherwise }\end{cases}$

High Temp Anomaly $i t= \begin{cases}T A_{i t} & \text { if } T A_{i t} \geq 0.10 \\ 0 & \text { otherwise }\end{cases}$

To estimate the impact of climate extremes on mean and variability of crop yields, we have used the stochastic production function approach formulated by Just and Pope (1978, 1979). By introducing a multiplicative heteroscedastic error term, the effect of inputs on yield variability (i.e., production risk) can be studied independent of its effect on mean

\footnotetext{
${ }^{28}$ Regression results are robust to alternative cut offs used for defining rainfall and temperature anomalies.
} 
yields.

The Just and Pope stochastic production function is:

$$
y=f(X, \beta)+\mu=f(X, \beta)+h(X, \alpha) \varepsilon
$$

where $y$ is output, $X$ is vector of inputs used in production, $f($.$) is production function$ relating $X$ to mean output where $\beta$ and $\alpha$ denote the vector of coefficients for the equations for mean yield and yield variability respectively, $h(X, \alpha)$ is the risk (variance) function, such that $h^{2}$ is the yield variance; $\varepsilon$ is random shock distributed with zero mean and unitary variance.

For estimation, we selected the major producing districts for each crop, comprising 163, 121 and 94 districts for rice, sorghum and pearl millet respectively. These districts account for 95 percent of average crop production during 1966-2011. Selected districts are listed in Appendix B.

By allowing for the possibility of including fixed effects, panel data models overcome the problem of omitted variable bias, usually encountered in cross sectional studies estimating the impact of climate change on agriculture (Blanc and Schlenker 2017). For estimation, we have used the method of Three Stage Feasible Generalized Least Squares (FGLS). The exact procedure is mentioned below (Just and Pope 1978;Cabas, Weersink, and Olale 2010). In the first stage we regress $y$ on $f(X, \beta)$ and obtain the least squares residuals, $\mu$ where $\hat{\mu}=y-f(X, \beta)$. In the second stage, $\ln \hat{\mu}^{2}$ is regressed on the variance function $(h(X, \alpha))$, where $h($.$) is assumed to be exponential. The second stage yields coefficient estimates of$ the yield variance function (i.e., $\alpha$ ). Predicted values of the residuals from second stage regression are used as weights for third stage regression. In the third stage, the first stage regression is re estimated using weights obtained from second stage. This yields coefficient estimates of the mean yield equation (Just and Pope 1978,1979).

Prior to estimation, all variables were tested for non stationarity using panel unit root 
tests and were found to be stationary. ${ }^{29}$ One expects input usage to be correlated with district specific time invariant attributes, such as land quality, farming techniques and sowing patterns, which makes the fixed effects model suitable for this study. Finally, we tested for fixed versus random effects using the Mundlak test and fixed effect model was found to be appropriate. Results have been reported in Table A.2. In light of these results panel corrected standard error (PCSE) estimates were obtained which correct for cross sectional dependence, heteroscedasticity and autocorrelation. Along with district fixed effects, time trends have also been included in the estimated equations capturing technological progress.

Two regressions were run for each crop, explaining crop mean yields and yield variability. Mean yield depends on climate and non climate inputs, namely, fertilizer, irrigation and use of high yielding variety seeds, whereas yield variability depends on the transformed climate variables (called climate anomalies). Further, to capture the effect of farming decisions at the extensive and intensive margin, gross cropped area under the crop has been included as a regressor in the mean yield regression. In Table 2 we also present results when mean yields and yield variability depend on levels of climate variables. Our results, however, show mean yields are best explained by levels of rainfall and temperature whereas variability in yields is more a function of variability in climate (anomalies). We surmise therefore it is variability in climate that makes agriculture more risky.

To capture asymmetric yield response to climate extremes we define four anomaly variables, capturing positive and negative deviations in rainfall and temperature from the long period average. These are termed as the drought, flood, low temperature and high temperature anomalies. Regression equations estimated for the three crops are:

$$
\begin{aligned}
{\text { Mean } \text { Yield }_{i t}=}_{1} & \beta_{1}+\alpha_{i}+\delta t+\beta_{2} \text { Area }_{i t}+\beta_{3} \text { Fertilizer }_{i t}+\beta_{4} \text { Irrigation }_{i t}+\beta_{5} H Y V_{i t}+ \\
& \beta_{6} \text { Rainfall }_{i t}+\beta_{7} \text { Temperature }_{i t}+\nu_{i t}
\end{aligned}
$$

\footnotetext{
${ }^{29} \mathrm{Im}$ Pesaran Shin (IPS) and Phillips Perron tests were performed to test for non stationarity. Results have been reported in Table A.1.
} 


$$
\begin{aligned}
&{\text { Yield } \text { Variance }_{i t}=} \gamma_{1}+\alpha_{i}+\delta t+\gamma_{2} \text { Drought Anomaly }_{i t}+\gamma_{3} \text { Flood Anomaly }_{i t}+ \\
& \gamma_{4} \text { Low Temp Anomaly }_{i t}+\gamma_{5} \text { High Temp Anomaly } \\
&+\xi_{i t}
\end{aligned}
$$

where $i$ refers to the district and $t$ refers to the year; $\alpha_{i}$ denotes district level fixed effects; Area $_{i t}$ denotes gross cropped area under the crop; Irrigation $i t$ is the proportion of gross cropped area (under that crop) which is irrigated; Fertilizer ${ }_{i t}$ is the total amount of fertilizers used (nitrogen, phosphate and potash) (per unit gross cropped area); $H Y V_{i t}$ is the proportion of gross cropped area (under that crop) under HYV seeds; Rain fall $_{i t}$ is the an-

nual rainfall; Temperature Te $_{i t}$ is the annual average temperature; Drought Anomaly it $_{\text {, Flood }}$ Anomaly $_{i t}$, Low Temp Anomaly An $_{\text {and High Temp Anomaly }}$ are the climate anomaly variables capturing rainfall and temperature extremes respectively; $\nu_{i t}$ and $\xi_{i t}$ are the stochastic error terms.

\section{Results}

For each crop, separate regressions were performed for mean yield and yield variance. The second stage regression yields estimates of coefficients of yield variance function $(h(X, \alpha))$, where as the third stage regression yields estimates of coefficients of mean yield $(f(X, \beta))$. In the estimated specifications, crop mean yield is assumed to be a function of the following variables: gross cropped area, proportion of gross cropped area irrigated, proportion of gross cropped area under HYV seeds, crop specific fertilizers used, annual rainfall and annual average temperature, whereas climate extremes, captured using climate anomalies are assumed to determine crop yield variability. To save space, coefficients of district fixed effects and time trend have been suppressed. Though not reported, coefficient of time trend is positive and significant across crops, indicating rising mean yields and yield variability over time due to technological progress.

Regression coefficients obtained in second and third stage regression denote marginal effects of inputs on crop mean yield and yield variability and. A positive (negative) coefficient 
is to be interpreted as an increase in input usage increasing crop mean yield and / or crop yield variability.

To determine the extent to which climate variables affect crop yields, we estimate regressions where levels of climate variables determine both mean yield and yield variance, results of which are reported in Tables 2-4 respectively. To isolate the effect of climate variables on crop yields from that of non climate variables, regressions dropping all inputs are reported in column (2). Moreover, the effect of climate variables on crop yields is non linear (Schlenker and Roberts 2009), results of which are reported in columns (3) and (4) respectively. From results reported in columns (1)-(4) in Tables 2-4, we see that like Barnwal and Kotani (2010),Arumugam et al (2015) and Chen et al (2004) higher rainfall increases crop yields whereas increases in temperature is detrimental for crop yields. The coefficient of rainfall is small but highly significant. Moreover, the effect of rainfall is non linear (column (3)), with increases in rainfall beyond 2857, 1000 and $1666 \mathrm{~mm}$ reducing mean yields of rice, sorghum and pearl millet respectively. Similarly, increases in temperature above 16.7 degree Celsius reduces rice yields, where as increases in temperature beyond 24.5 degree Celsius lowers pearl millet yields. For yield variability regression, we find that like Kim and Pang (2009) increases in temperature increase rice yield variability. Results for rainfall are similar to those in Poudel, Chen and Huang (2014) where increase in rainfall reduces rice yield variability. However, we find that yield variance is better explained by climate anomalies, than levels of weather variables. The coefficient of temperature is positive but insignificant for rice and sorghum (columns (1) and (2) respectively). Further, the role of non climate variables is limited in determining yield variance for the three crops.

Inter annual fluctuations in rainfall and temperature affect crop yields through its effect on crop development, where as climate anomalies affect farmer's crop management decisions (such as, frequency and quantity of inputs to be used, combination of crops to be produced), thus affecting crop yields indirectly (Arshad et al 2016). Thus, we estimate regressions where mean yield is a function of level of climate variables, where as climate anomalies determine crop yield variability, results of which are reported in Tables 5-7 and are discussed below. 
Table 2: Level of Climate Variables determines Crop Yields (Rice)

$$
\begin{array}{ll}
\text { E-04*** } & 6 \mathrm{E}-05^{* * *} \\
(2 \mathrm{E}-05) & (2 \mathrm{E}-05)
\end{array}
$$

Rainfall $^{2}$

Temperature

Temperature $^{2}$

Area

Irrigation

HYV

$N$

Yield Variance

Rainfall

Rainfall $^{2}$

Temperature

Temperature ${ }^{2}$

Fertilizer

$$
-0.038
$$

(1)

7513

(2)

$$
\begin{aligned}
& -0.124^{* * *} \\
& (0.014)
\end{aligned}
$$

(0.012)

$0.001^{* * *}$
$(\mathrm{E}-04)$

$3.867^{* * *}$

(0.180)

$0.397^{* * *}$

(0.049)

$0.385^{* * *}$

(0.024)

5047
$-0.001^{* * *}$

(E-04)
(3)

(4)
$4 \mathrm{E}-04^{* * *}$

(4E-05)

$-7 \mathrm{E}-08^{* * *}$

(E-08)

0.207

(0.166)

$-0.006^{*}$

(0.003)

$0.001^{* * *}$

(E-04)

$3.827^{* * *}$

(0.179)

$0.405^{* * *}$

(0.048)

$0.383^{* * *}$

(0.024)

5047

7513
$3 \mathrm{E}-04^{* * *}$

(4E-05)

$-6 \mathrm{E}-08^{* * *}$

(9E-09)

0.033

(0.155)

$-0.002$

(0.003)

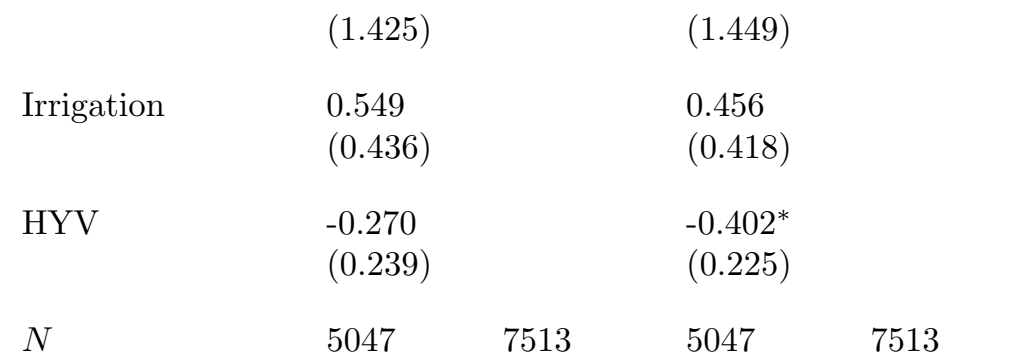

Notes: In this table and all others that follow robust standard errors in parentheses. ${ }^{* * *},{ }^{* *}$, and $*$ indicate $1 \%, 5 \%$, and $10 \%$ significance levels. Coefficients of district fixed effects and time trend have been suppressed. 
Table 3: Level of Climate Variables determines Crop Yields (Sorghum)

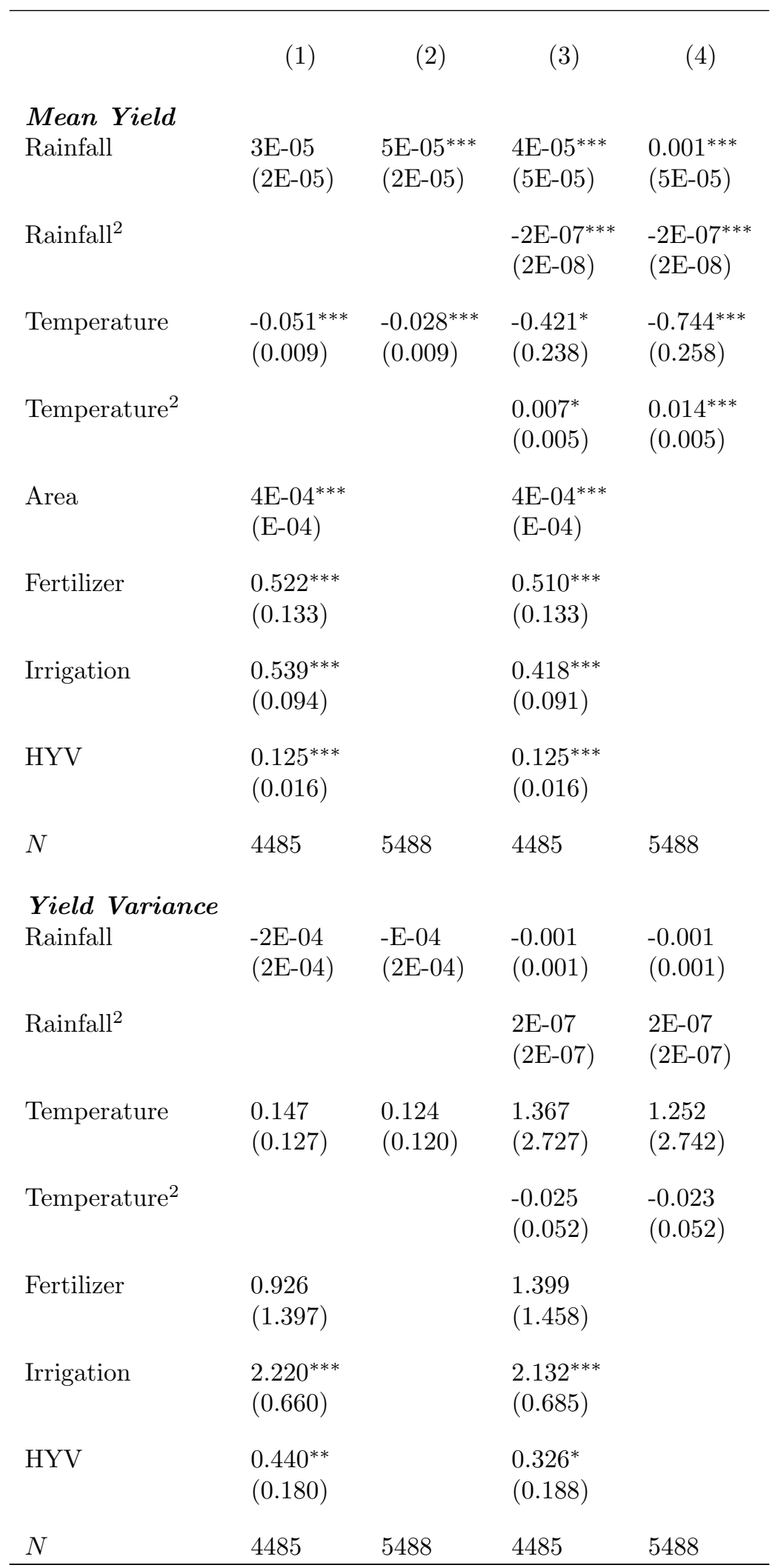


Table 4: Level of Climate Variables determines Crop Yields (Pearl Millet)

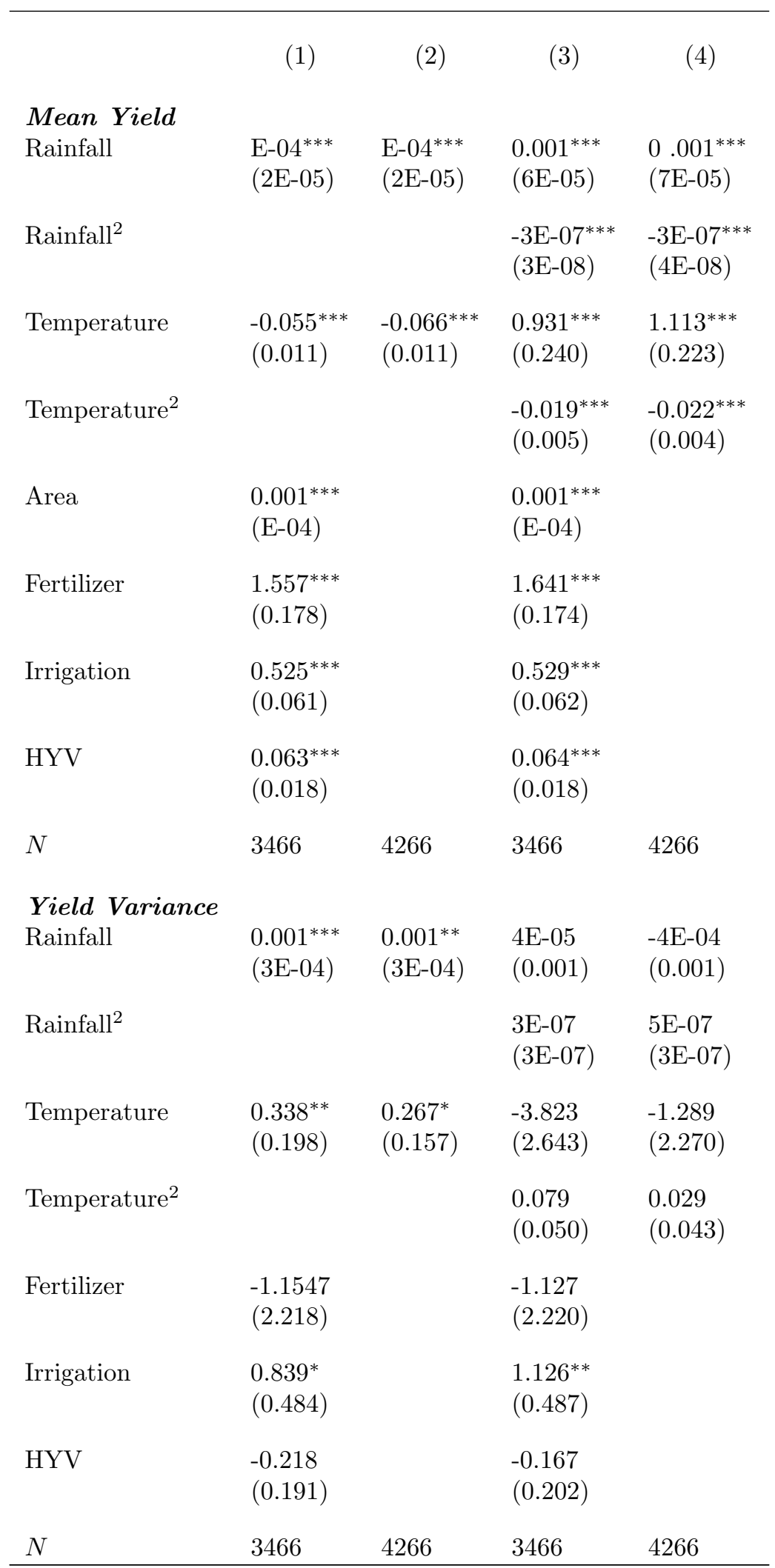




\section{Rice}

Results reported in column (1) of Table 5 indicate that for the mean yield regression, coef-

ficients of all variables are statistically significant and of the expected signs. Coefficients of irrigation, fertilizer and HYV variables are positive and significant, even at 1 percent level of significance. Regression coefficients can be interpreted as follows: with a yield elasticity of 0.12 , acreage expansion increases rice yields. As expected, rice is input intensive. With a yield elasticity of 0.17 , using an extra tonne of fertilizer (per unit gross cropped area) increases yields by $3897 \mathrm{~kg} / \mathrm{ha}$. Similarly, irrigation expansion and use of high yielding variety seeds increases rice yields. With a yield elasticity of 0.13 , irrigation expansion is expected to increase mean rice yields. Similarly, elasticity of rice yields with increased use of HYV is 0.11. Since rice is a water-intensive crop, higher rainfall increases rice yields. However, the coefficient is small in magnitude with a $100 \mathrm{~mm}$ increase in rainfall increasing yields by 10 $\mathrm{kg} / \mathrm{ha}$. Increases in temperature reduces yields, rice yields falling by $122 \mathrm{~kg} / \mathrm{ha}$ per degree Celsius increase in temperature.

The yield variability regression is log linear, with coefficients representing semi elasticities. Like Arshad et al (2016), we find that yield variance increases with increases in rainfall anomaly. The crop is particularly sensitive to fluctuations in rainfall. Coefficients of both, drought and flood anomaly variables are positive and significant, hence rainfall variability, particularly rainfall extremes increase rice yield variability significantly. Both positive and negative deviations in rainfall from long period average increase rice yield variability. An annual rainfall of $100 \mathrm{~mm}$ below long period average increases yield variability by 10 percent. An annual rainfall of $100 \mathrm{~mm}$ rainfall above long period average increases yield variability by smaller amount, i.e., 5 percent. Temperatures exceeding the long period average are particularly detrimental, with yield variability increasing by 35 percent for temperatures exceeding the long period average by 1 degree Celsius. Hence, fluctuations in rainfall and increasingly higher positive deviations in temperature from long period average ameliorate yield variability, which is expected since the crop is sensitive to short term and long term 
Table 5: Level of Climate Variables determines Mean Yield and Climate Anomalies determine Yield Variance (Rice)

\begin{tabular}{|c|c|c|c|c|c|c|}
\hline & (1) & $(2)$ & (3) & $(4)$ & $(5)$ & (6) \\
\hline $\begin{array}{l}\text { Mean Yield } \\
\text { Rainfall }\end{array}$ & $\begin{array}{l}\text { E-04*** } \\
(2 \mathrm{E}-05)\end{array}$ & $\begin{array}{l}4 \mathrm{E}-04^{* * *} \\
(5 \mathrm{E}-05)\end{array}$ & $\begin{array}{l}6 \mathrm{E}-05^{* * *} \\
(2 \mathrm{E}-05)\end{array}$ & $\begin{array}{l}\text { E- } 04^{* * *} \\
(2 \mathrm{E}-05)\end{array}$ & $\begin{array}{l}\text { E-04*** } \\
(2 \mathrm{E}-05)\end{array}$ & $\begin{array}{l}2 \mathrm{E}-04^{* *} \\
(3 \mathrm{E}-05)\end{array}$ \\
\hline Rainfall $^{2}$ & & $\begin{array}{l}-7 \mathrm{E}-08^{* * *} \\
(\mathrm{E}-08)\end{array}$ & & & & \\
\hline Temperature & $\begin{array}{l}-0.122^{* * *} \\
(0.014)\end{array}$ & $\begin{array}{l}0.167 \\
(0.169)\end{array}$ & $\begin{array}{l}-0.143^{* * *} \\
(0.012)\end{array}$ & $\begin{array}{l}-0.122^{* * *} \\
(0.014)\end{array}$ & $\begin{array}{l}-0.141^{* * *} \\
(0.011)\end{array}$ & $\begin{array}{l}-0.157^{* * *} \\
(0.014)\end{array}$ \\
\hline Temperature $^{2}$ & & $\begin{array}{l}-0.005 \\
(0.003)\end{array}$ & & & & \\
\hline Rainfall*Temperature & & & & & & $\begin{array}{l}3 \mathrm{E}-05^{* * *} \\
(\mathrm{E}-05)\end{array}$ \\
\hline GSDD & & & & & $\begin{array}{l}-0.001^{* * *} \\
(10 \mathrm{E}-05)\end{array}$ & \\
\hline Area & $\begin{array}{l}0.001^{* * *} \\
(\mathrm{E}-04)\end{array}$ & $\begin{array}{l}0.001^{* * *} \\
(\mathrm{E}-04)\end{array}$ & & $\begin{array}{l}0.001^{* * *} \\
(\mathrm{E}-04)\end{array}$ & $\begin{array}{l}0.001^{* * *} \\
(\mathrm{E}-04)\end{array}$ & $\begin{array}{l}0.001^{* * *} \\
(\mathrm{E}-04)\end{array}$ \\
\hline Fertilizer & $\begin{array}{l}3.897^{* * *} \\
(0.180)\end{array}$ & $\begin{array}{l}3.890^{* * *} \\
(0.179)\end{array}$ & & $\begin{array}{l}3.895^{* * *} \\
(0.179)\end{array}$ & $\begin{array}{l}4.045^{* * *} \\
(0.180)\end{array}$ & $\begin{array}{l}3.926^{* * *} \\
(0.180)\end{array}$ \\
\hline Irrigation & $\begin{array}{l}0.380^{* * *} \\
(0.049)\end{array}$ & $\begin{array}{l}0.386^{* * *} \\
(0.049)\end{array}$ & & $\begin{array}{l}0.382^{* * *} \\
(0.049)\end{array}$ & $\begin{array}{l}0.421^{* * *} \\
(0.049)\end{array}$ & $\begin{array}{l}0.388^{* * *} \\
(0.049)\end{array}$ \\
\hline HYV & $\begin{array}{l}0.399^{* * *} \\
(0.024)\end{array}$ & $\begin{array}{l}0.399^{* * *} \\
(0.024)\end{array}$ & & $\begin{array}{l}0.398^{* * *} \\
(0.024)\end{array}$ & $\begin{array}{l}0.400^{* * *} \\
(0.024)\end{array}$ & $\begin{array}{l}0.387^{* * *} \\
(0.024)\end{array}$ \\
\hline$N$ & 5047 & 5047 & 7513 & 5047 & 5047 & 5047 \\
\hline $\begin{array}{l}\text { Yield Variance } \\
\text { Drought Anomaly }\end{array}$ & $\begin{array}{l}0.001^{* * *} \\
(3 \mathrm{E}-04)\end{array}$ & $\begin{array}{l}0.001^{* * *} \\
(3 \mathrm{E}-04)\end{array}$ & $\begin{array}{l}0.001^{* * *} \\
(3 \mathrm{E}-04)\end{array}$ & & $\begin{array}{l}0.001^{* * *} \\
(3 \mathrm{E}-04)\end{array}$ & $\begin{array}{l}0.001^{* * *} \\
(3 \mathrm{E}-04)\end{array}$ \\
\hline Flood Anomaly & $\begin{array}{l}5 \mathrm{E}-04^{* *} \\
(3 \mathrm{E}-04)\end{array}$ & $\begin{array}{l}0.001^{* * *} \\
(3 \mathrm{E}-04)\end{array}$ & $\begin{array}{l}2 \mathrm{E}-05 \\
(2 \mathrm{E}-04)\end{array}$ & & $\begin{array}{l}0.001^{* *} \\
(3 \mathrm{E}-04)\end{array}$ & $\begin{array}{l}0.001^{* *} \\
(3 \mathrm{E}-04)\end{array}$ \\
\hline Low Temp Anomaly & $\begin{array}{l}0.083 \\
(0.201)\end{array}$ & $\begin{array}{l}0.061 \\
(0.200)\end{array}$ & $\begin{array}{l}0.146 \\
(0.207)\end{array}$ & & $\begin{array}{l}0.031 \\
(0.220)\end{array}$ & $\begin{array}{l}0.086 \\
(0.201)\end{array}$ \\
\hline High Temp Anomaly & $\begin{array}{l}0.351^{*} \\
(0.196)\end{array}$ & $\begin{array}{l}0.367^{*} \\
(0.194)\end{array}$ & $\begin{array}{l}0.144 \\
(0.188)\end{array}$ & & $\begin{array}{l}0.459^{* *} \\
(0.201)\end{array}$ & $\begin{array}{l}0.308 \\
(0.195)\end{array}$ \\
\hline Std Drought Anomaly & & & & $\begin{array}{l}0.155^{* * *} \\
(0.039)\end{array}$ & & \\
\hline Std Flood Anomaly & & & & $\begin{array}{l}0.076^{*} \\
(0.041)\end{array}$ & & \\
\hline Std Low Temp Anomaly & & & & $\begin{array}{l}0.016 \\
(0.042)\end{array}$ & & \\
\hline Std High Temp Anomaly & & & & $\begin{array}{l}0.102^{* *} \\
(0.049)\end{array}$ & & \\
\hline Fertilizer & & & & & & $\begin{array}{l}0.161 \\
(1.443)\end{array}$ \\
\hline Irrigation & & & & & & $\begin{array}{l}0.570 \\
(0.429)\end{array}$ \\
\hline HYV & & & & & & $\begin{array}{l}-0.234 \\
(0.238)\end{array}$ \\
\hline$N$ & 5047 & 5047 & 7513 & 5047 & 5047 & 5047 \\
\hline
\end{tabular}


fluctuations in weather.

Accounting for non linear effects of climate variables in column (2) of Table 5, we see that increases in rainfall increases yields at a decreasing rate, with a turning point at 2857 $\mathrm{mm}$, which far exceeds average rainfall needed for rice production. The impact of increases in temperature is also non linear, with temperature exceeding 16.7 degree Celsius reducing yields. Dropping all non climate inputs in mean yield regression increases the coefficient of temperature slightly, with a degree Celsius increase in temperature reducing mean yield by $143 \mathrm{~kg} / \mathrm{ha}$ (column (3)). To account for differences in unit of measurement, we also estimate results by standardizing the climate anomalies (column(4)). It can be seen that results are qualitatively similar to those in column (1), with an increase in rainfall and decrease in temperature reducing mean yield. Cumulative heat during the growing season (captured using growing season degree days) also reduces mean yields (column(5)). Moreover, an increase in rainfall does not mitigate the adverse effects of higher temperature (column(6)). This is evident from the small magnitude of coefficient of interaction term between rainfall and temperature.

Results for yield variability reported in columns (2)-(6) of Table 5 indicate that increases in drought and flood anomaly increase rice yield variability. Results for standardized climate anomalies (in column(4)) help understand the relative importance of climate anomalies in determining crop yield variability. A comparison of coefficients of standardized drought and flood anomalies indicates that deviations in rainfall below long period average affect the crop much more adversely than positive deviations in rainfall do. Clearly, drought anomaly and high temp anomaly increase rice yield variability. Moreover, non climate variables do not matter for rice yield variability $(\operatorname{column}(6))$.

\section{Sorghum}

From results reported in column (1) of Table 6, we see that acreage expansion increases mean yields, however, the coefficient is small in magnitude. Coefficients of irrigation, fertilizer and 
Table 6: Level of Climate Variables determines Mean Yield and

Climate Anomalies determine Yield Variance (Sorghum)

\begin{tabular}{|c|c|c|c|c|c|c|}
\hline & (1) & $(2)$ & $(3)$ & (4) & $(5)$ & (6) \\
\hline $\begin{array}{l}\text { Mean Yield } \\
\text { Rainfall }\end{array}$ & $\begin{array}{l}3 \mathrm{E}-05^{*} \\
(2 \mathrm{E}-05)\end{array}$ & $\begin{array}{l}4 \mathrm{E}-04^{* * *} \\
(5 \mathrm{E}-05)\end{array}$ & $\begin{array}{l}6 \mathrm{E}-05^{* * *} \\
(2 \mathrm{E}-05)\end{array}$ & $\begin{array}{l}3 \mathrm{E}-05 \\
(2 \mathrm{E}-05)\end{array}$ & $\begin{array}{l}5 \mathrm{E}-05^{* * *} \\
(2 \mathrm{E}-05)\end{array}$ & $\begin{array}{l}-0.002^{* * *} \\
(4 \mathrm{E}-04)\end{array}$ \\
\hline Rainfall $^{2}$ & & $\begin{array}{l}-2 \mathrm{E}-07^{* * *} \\
(2 \mathrm{E}-08)\end{array}$ & & & & \\
\hline Temperature & $\begin{array}{l}-0.045^{* * *} \\
(0.010)\end{array}$ & $\begin{array}{l}-0.428^{*} \\
(0.255)\end{array}$ & $\begin{array}{l}-0.021^{* *} \\
(0.009)\end{array}$ & $\begin{array}{l}-0.047^{* * *} \\
(0.010)\end{array}$ & $\begin{array}{l}0.212 \\
(0.166)\end{array}$ & $\begin{array}{l}-0.109^{* * *} \\
(0.015)\end{array}$ \\
\hline Temperature $^{2}$ & & $\begin{array}{l}0.008 \\
(0.005)\end{array}$ & & & & \\
\hline Rainfall*Temperature & & & & & & $\begin{array}{l}8 \mathrm{E}-05^{* * *} \\
(\mathrm{E}-05)\end{array}$ \\
\hline GSDD & & & & & $\begin{array}{l}-9 \mathrm{E}-05 \\
(7 \mathrm{E}-05)\end{array}$ & \\
\hline Area & $\begin{array}{l}4 \mathrm{E}-04^{* * *} \\
(\mathrm{E}-04)\end{array}$ & $\begin{array}{l}4 \mathrm{E}-04^{* * *} \\
(\mathrm{E}-04)\end{array}$ & & $\begin{array}{l}4 \mathrm{E}-04^{* * *} \\
(\mathrm{E}-04)\end{array}$ & $\begin{array}{l}4 \mathrm{E}-04^{* * *} \\
(10 \mathrm{E}-05)\end{array}$ & $\begin{array}{l}4 \mathrm{E}-04^{* * *} \\
(\mathrm{E}-04)\end{array}$ \\
\hline Fertilizer & $\begin{array}{l}0.543^{* * *} \\
(0.133)\end{array}$ & $\begin{array}{l}0.498^{* * *} \\
(0.131)\end{array}$ & & $\begin{array}{l}0.552^{* * *} \\
(0.133)\end{array}$ & $\begin{array}{l}0.474^{* * *} \\
(0.131)\end{array}$ & $\begin{array}{l}0.450^{* * *} \\
(0.134)\end{array}$ \\
\hline Irrigation & $\begin{array}{l}0.591^{* * *} \\
(0.082)\end{array}$ & $\begin{array}{l}0.380^{* * *} \\
(0.079)\end{array}$ & & $\begin{array}{l}0.590^{* * *} \\
(0.082)\end{array}$ & $\begin{array}{l}0.412^{* * *} \\
(0.081)\end{array}$ & $\begin{array}{l}0.496^{* * *} \\
(0.092)\end{array}$ \\
\hline HYV & $\begin{array}{l}0.123^{* * *} \\
(0.016)\end{array}$ & $\begin{array}{l}0.122^{* * *} \\
(0.016)\end{array}$ & & $\begin{array}{l}0.123^{* * *} \\
(0.016)\end{array}$ & $\begin{array}{l}0.124^{* * *} \\
(0.016)\end{array}$ & $\begin{array}{l}0.123^{* * *} \\
(0.016)\end{array}$ \\
\hline$N$ & 4485 & 4485 & 5488 & 4485 & 4485 & 4485 \\
\hline $\begin{array}{l}\text { Yield Variance } \\
\text { Drought Anomaly }\end{array}$ & $\begin{array}{l}0.001^{* * *} \\
(4 \mathrm{E}-04)\end{array}$ & $\begin{array}{l}0.001^{* * *} \\
(4 \mathrm{E}-04)\end{array}$ & $\begin{array}{l}0.002^{* * *} \\
(4 \mathrm{E}-04)\end{array}$ & & $\begin{array}{l}0.001^{* * *} \\
(4 \mathrm{E}-04)\end{array}$ & $\begin{array}{l}0.001^{* * *} \\
(4 \mathrm{E}-04)\end{array}$ \\
\hline Flood Anomaly & $\begin{array}{l}4 \mathrm{E}-04 \\
(3 \mathrm{E}-04)\end{array}$ & $\begin{array}{l}\text { E-04 } \\
(3 \mathrm{E}-04)\end{array}$ & $\begin{array}{l}0.001^{* * *} \\
(3 \mathrm{E}-04)\end{array}$ & & $\begin{array}{l}3 \mathrm{E}-04 \\
(3 \mathrm{E}-04)\end{array}$ & $\begin{array}{l}2 \mathrm{E}-04 \\
(3 \mathrm{E}-04)\end{array}$ \\
\hline Low Temp Anomaly & $\begin{array}{l}0.486^{* *} \\
(0.204)\end{array}$ & $\begin{array}{l}0.596^{* * *} \\
(0.208)\end{array}$ & $\begin{array}{l}0.320 \\
(0.195)\end{array}$ & & $\begin{array}{l}0.518^{* *} \\
(0.206)\end{array}$ & $\begin{array}{l}0.585^{* * *} \\
(0.203)\end{array}$ \\
\hline High Temp Anomaly & $\begin{array}{l}0.641^{* * *} \\
(0.196)\end{array}$ & $\begin{array}{l}0.627^{* * *} \\
(0.197)\end{array}$ & $\begin{array}{l}0.373^{* *} \\
(0.173)\end{array}$ & & $\begin{array}{l}0.635^{* * *} \\
(0.201)\end{array}$ & $\begin{array}{l}0.542^{* * *} \\
(0.196)\end{array}$ \\
\hline Std Drought Anomaly & & & & $\begin{array}{l}0.132^{* * *} \\
(0.042)\end{array}$ & & \\
\hline Std Flood Anomaly & & & & $\begin{array}{l}0.026 \\
(0.047)\end{array}$ & & \\
\hline Std Low Temp Anomaly & & & & $\begin{array}{l}0.108^{* *} \\
(0.044)\end{array}$ & & \\
\hline Std High Temp Anomaly & & & & $\begin{array}{l}0.146^{* * *} \\
(0.058)\end{array}$ & & \\
\hline Fertilizer & & & & & & $\begin{array}{l}1.715 \\
(1.406)\end{array}$ \\
\hline Irrigation & & & & & & $\begin{array}{l}1.912^{* * *} \\
(0.672)\end{array}$ \\
\hline HYV & & & & & & $\begin{array}{l}0.443^{* *} \\
(0.178)\end{array}$ \\
\hline$N$ & 4485 & 4485 & 5488 & 4485 & 4485 & 4485 \\
\hline
\end{tabular}


HYV variables are positive and highly significant, even at 1 percent level of significance. An extra tonne of fertilizer applied (per unit gross cropped area) increases yields by 543 $\mathrm{kg} /$ ha. Similarly, irrigation expansion and use of high yielding variety seeds increases yields, with an increase in sorghum irrigated area (as a proportion of gross cropped area) by 0.10 yielding an additional $59 \mathrm{~kg} / \mathrm{ha}$, use of high yielding variety seeds also increases yields by $12 \mathrm{~kg} / \mathrm{ha}$. However, in comparison to rice, sorghum is less input intensive. The elasticity of sorghum yield with respect to fertilizer, irrigation and HYV is 0.03, 0.029, and 0.04 respectively, which is much higher for rice. Coefficient of rainfall is small but significant. Like Arumugam et al (2015), we find that increases in rainfall and reduction in temperature increases yields. Higher rainfall is beneficial, with sorghum yields increasing by $3 \mathrm{~kg} / \mathrm{ha}$ per $100 \mathrm{~mm}$ increase in rainfall. Higher temperature adversely affects average yields, with yields falling by $45 \mathrm{~kg} /$ ha per degree Celsius increase in temperature.

Like Arumugam et al (2015), Mc Carl Villavicencio and Wu (2008) we find that sorghum yields are sensitive to variability in rainfall and temperature, as reflected by positive and significant coefficients of rainfall and temperature anomalies. An annual rainfall of $100 \mathrm{~mm}$ below long period average increases yield variability by 10 percent. Among temperature anomalies, temperatures exceeding long period average are detrimental, increasing yield variability by 64 percent per degree Celsius increase in temperature from long period average. Deviations in temperature of a similar magnitude below the long period average increase yield variability by a smaller amount (49 percent).

Accounting for non linear effects of climate variables in column (2) of Table 6, we see that increases in rainfall increases yields at a decreasing rate, with a turning point at $1000 \mathrm{~mm}$, which exceeds the average rainfall required for sorghum production. The impact of increases in temperature is also non linear, however, the coefficient of temperature is insignificant. Dropping all non climate inputs from mean yield regression does not qualitatively change the results, with increases in rainfall and decrease in temperature increasing sorghum yield (column (3)). To account for differences in unit of measurement, we also estimate results by standardizing the climate anomalies (column(4)). It can be seen that results are qualitatively 
similar to those in column (1). Cumulative heat during the growing season also reduces mean yields (column(5)). Moreover, an increase in rainfall does not mitigate the adverse effects of higher temperature, as is evident from magnitude of coefficient of interaction term between rainfall and temperature $(\operatorname{column}(6))$.

Results for yield variability reported in columns (2)-(6) indicate that increases in drought anomaly and high temp anomaly increase sorghum yield variability. Results for standardized climate anomalies (in column(4)) indicates that higher drought anomaly and temperature anomalies increase sorghum yield variability. Among non climate variables, we see that irrigation expansion and use of high yielding variety seeds increases yield variability (column(6)). An increase in sorghum irrigated area (as a proportional of gross cropped area) by 0.10 increases yield variability by 19 percent, with increases in area under HYV of a similar magnitude increasing yield variability by 4 percent. These results are consistent with those in Guttormsen and Roll (2013), who also find increased irrigation expansion to increase risk in production since farmers use traditional methods of irrigation which are labor intensive and involve wastage of water. Increased use of HYV seeds increases water requirement of crops increasing yield variability further.

\section{Pearl Millet}

From results reported in column (1) of Table 7, we see that with a yield elasticity of 0.135 , acreage expansion increases yields marginally. Coefficients of irrigation, fertilizer and HYV variables are positive and highly significant, even at 1 percent level of significance. Among the three inputs, yield elasticity is highest for fertilizer (at 0.111). An extra tonne of fertilizer applied (per unit gross cropped area) increases yields by $1521 \mathrm{~kg} / \mathrm{ha}$. Yield elasticity with respect to irrigation expansion and use of HYV is 0.08 and 0.03 respectively. Further, higher rainfall increases yields, with an increase of $20 \mathrm{~kg} /$ ha per $100 \mathrm{~mm}$ increase in rainfall. Higher temperature adversely affects yields with a decrease of $49 \mathrm{~kg} / \mathrm{ha}$ per degree Celsius increase in temperature. 
Table 7: Level of Climate Variables determines Mean Yield and

Climate Anomalies determine Yield Variance (Pearl Millet)

\begin{tabular}{|c|c|c|c|c|c|c|}
\hline & (1) & $(2)$ & $(3)$ & $(4)$ & (5) & (6) \\
\hline $\begin{array}{l}\text { Mean Yield } \\
\text { Rainfall }\end{array}$ & $\begin{array}{l}2 \mathrm{E}-04^{* * *} \\
(2 \mathrm{E}-05)\end{array}$ & $\begin{array}{l}0.001^{* * *} \\
(5 \mathrm{E}-05)\end{array}$ & $\begin{array}{l}6 \mathrm{E}-04^{* * *} \\
(5 \mathrm{E}-04)\end{array}$ & $\begin{array}{l}\text { E- } 04^{* * *} \\
(2 \mathrm{E}-05)\end{array}$ & $\begin{array}{l}5 \mathrm{E}-05^{* * *} \\
(2 \mathrm{E}-05)\end{array}$ & $\begin{array}{l}-0.003^{* * *} \\
(4 \mathrm{E}-04)\end{array}$ \\
\hline Rainfall $^{2}$ & & $\begin{array}{l}-2 \mathrm{E}-07^{* * *} \\
(2 \mathrm{E}-08)\end{array}$ & & & & \\
\hline Temperature & $\begin{array}{l}-0.049^{* * *} \\
(0.011)\end{array}$ & $\begin{array}{l}-0.982^{* * *} \\
(0.247)\end{array}$ & $\begin{array}{l}-0.060^{* *} \\
(0.011)\end{array}$ & $\begin{array}{l}-0.052^{* * *} \\
(0.011)\end{array}$ & & $\begin{array}{l}-0.120^{* * *} \\
(0.016)\end{array}$ \\
\hline Temperature $^{2}$ & & $\begin{array}{l}-0.020^{* * *} \\
(0.005)\end{array}$ & & & & \\
\hline Rainfall*Temperature & & & & & & $\begin{array}{l}\text { E-04*** } \\
(2 \mathrm{E}-05)\end{array}$ \\
\hline GSDD & & & & & $\begin{array}{l}-5 \mathrm{E}-04^{* * *} \\
(8 \mathrm{E}-05)\end{array}$ & \\
\hline Area & $\begin{array}{l}0.001^{* * *} \\
(\mathrm{E}-04)\end{array}$ & $\begin{array}{l}0.001^{* * *} \\
(\mathrm{E}-04)\end{array}$ & & $\begin{array}{l}0.001^{* * *} \\
(\mathrm{E}-04)\end{array}$ & $\begin{array}{l}0.001^{* * *} \\
(\mathrm{E}-04)\end{array}$ & $\begin{array}{l}0.001^{* * *} \\
(\mathrm{E}-04)\end{array}$ \\
\hline Fertilizer & $\begin{array}{l}1.521^{* * *} \\
(0.181)\end{array}$ & $\begin{array}{l}1.615^{* * *} \\
(0.178)\end{array}$ & & $\begin{array}{l}1.539^{* * *} \\
(0.181)\end{array}$ & $\begin{array}{l}1.417^{* * *} \\
(0.183)\end{array}$ & $\begin{array}{l}1.373^{* * *} \\
(0.180)\end{array}$ \\
\hline Irrigation & $\begin{array}{l}0.552^{* * *} \\
(0.060)\end{array}$ & $\begin{array}{l}0.571^{* * *} \\
(0.060)\end{array}$ & & $\begin{array}{l}0.544^{* * *} \\
(0.060)\end{array}$ & $\begin{array}{l}0.526^{* * *} \\
(0.059)\end{array}$ & $\begin{array}{l}0.485^{* * *} \\
(0.059)\end{array}$ \\
\hline HYV & $\begin{array}{l}0.061^{* * *} \\
(0.018)\end{array}$ & $\begin{array}{l}0.063^{* * *} \\
(0.018)\end{array}$ & & $\begin{array}{l}0.061^{* * *} \\
(0.018)\end{array}$ & $\begin{array}{l}0.065^{* * *} \\
(0.018)\end{array}$ & $\begin{array}{l}0.049^{* * *} \\
(0.019)\end{array}$ \\
\hline$N$ & 3466 & 3466 & 4266 & 3466 & 3466 & 3466 \\
\hline $\begin{array}{l}\text { Yield Variance } \\
\text { Drought Anomaly }\end{array}$ & $\begin{array}{l}4 \mathrm{E}-04 \\
(0.001)\end{array}$ & $\begin{array}{l}-\mathrm{E}-04 \\
(0.001)\end{array}$ & $\begin{array}{l}0.001 \\
(5 \mathrm{E}-04)\end{array}$ & & $\begin{array}{l}2 \mathrm{E}-04 \\
(5 \mathrm{E}-04)\end{array}$ & $\begin{array}{l}4 \mathrm{E}-04 \\
(0.001)\end{array}$ \\
\hline Flood Anomaly & $\begin{array}{l}0.001^{* * *} \\
(4 \mathrm{E}-04)\end{array}$ & $\begin{array}{l}0.001^{* *} \\
(4 \mathrm{E}-04)\end{array}$ & $\begin{array}{l}0.001^{* * *} \\
(4 \mathrm{E}-04)\end{array}$ & & $\begin{array}{l}0.002^{* * *} \\
(4 \mathrm{E}-04)\end{array}$ & $\begin{array}{l}0.001^{* * *} \\
(4 \mathrm{E}-04)\end{array}$ \\
\hline Low Temp Anomaly & $\begin{array}{l}-0.009 \\
(0.273)\end{array}$ & $\begin{array}{l}0.128 \\
(0.279)\end{array}$ & $\begin{array}{l}0.276 \\
(0.270)\end{array}$ & & $\begin{array}{l}0.123 \\
(0.273)\end{array}$ & $\begin{array}{l}0.232 \\
(0.278)\end{array}$ \\
\hline High Temp Anomaly & $\begin{array}{l}0.625^{* *} \\
(0.267)\end{array}$ & $\begin{array}{l}0.627^{* *} \\
(0.270)\end{array}$ & $\begin{array}{l}0.564^{* *} \\
(0.240)\end{array}$ & & $\begin{array}{l}0.751^{* * *} \\
(0.254)\end{array}$ & $\begin{array}{l}0.618^{* *} \\
(0.268)\end{array}$ \\
\hline Std Drought Anomaly & & & & $\begin{array}{l}0.047 \\
(0.053)\end{array}$ & & \\
\hline Std Flood Anomaly & & & & $\begin{array}{l}0.173^{* * *} \\
(0.057)\end{array}$ & & \\
\hline Std Low Temp Anomaly & & & & $\begin{array}{l}-0.004 \\
(0.057)\end{array}$ & & \\
\hline Std High Temp Anomaly & & & & $\begin{array}{l}0.181^{* *} \\
(0.075)\end{array}$ & & \\
\hline Fertilizer & & & & & & $\begin{array}{l}-1.732 \\
(2.184)\end{array}$ \\
\hline Irrigation & & & & & & $\begin{array}{l}0.832 \\
(0.518)\end{array}$ \\
\hline HYV & & & & & & $\begin{array}{c}-0.428^{* *} \\
(0.195)\end{array}$ \\
\hline$N$ & 3466 & 3466 & 4266 & 3466 & 3466 & 3466 \\
\hline
\end{tabular}


For the yield variability regression, we see that flood anomaly and high temperature anomaly variables are positive and significant. An annual rainfall of $100 \mathrm{~mm}$ above the long period average increases yield variability by 10 percent. Temperatures exceeding the long period average are particularly harmful, with yield variability increasing by 63 percent per degree Celsius increase in temperature above long period average.

Accounting for non linear effects of climate variables in column (2) of Table 7, we see that increases in rainfall increases yields at a decreasing rate, with a turning point at 2500 $\mathrm{mm}$, which far exceeds the average rainfall required for pearl millet production. The impact of increases in temperature is also non linear, with temperature exceeding 24.5 degree Celsius particularly detrimental for yields. Dropping all non climate inputs from mean yield regression does not qualitatively change the results, with increases in rainfall and decrease in temperature increasing crop yields (column (3)). However, the coefficient of temperature has increased, with yields decreasing by $60 \mathrm{~kg} /$ ha per degree Celsius increase in temperature. To account for differences in unit of measurement, we also estimate results by standardizing climate anomalies (column(4)). It can be seen that results are qualitatively similar to those in column (1). Cumulative heat during the growing season also reduces mean yields (column(5)). However, the coefficient is small in magnitude. Moreover, an increase in rainfall does not mitigate the adverse effects of higher temperature, as is evident from magnitude of coefficient of interaction term between rainfall and temperature (column(6)). We find qualitatively similar results for yield variability in columns (2)-(6). Among non climate variables, we see that use of HYV seeds increases yield variability, with an increase in area under HYV (as a proportion of gross cropped area) by 0.10 reducing pearl millet yield variability by 4 percent $(\operatorname{column}(6))$.

\section{Robustness Checks}

Through its effects on farmer's production decisions, climate anomalies matter for crop yields. Considering this, we performed a variety of robustness checks, results of which are 
reported in Tables 8-10, where both mean yields and yield variance are a function of climate anomalies. Results for the full specification, where both climate and non climate variables determine mean yield and yield variability are reported in column (1). Reported in column (2) are results for the specification where we drop all non climate inputs from the regression. Results with standardized climate anomalies are reported in column (3). Since irrigation expansion and use of HYV seeds is complementary, results dropping HYV are reported in column (4). Owing to non availability of data on crop specific fertilizer use, we also report results dropping fertilizer variable from mean yield regression in column (5).

Results for rice yield are reported in columns (1)-(5) of Table 8. Like Arshad et al (2016) and Chang (2002) we find that climate anomalies matter for mean yields, with increases in drought, flood and high temperature anomalies reducing rice yields significantly. Our results are also consistent with those in Mc Carl Villavicencio and Wu (2008), Barnwal and Kotani (2010) and Arumugam et al (2015), who also find variability in climate variables to be increasing crop yield variability. A comparison of coefficients of drought and flood anomaly variables indicates that deviations in rainfall below long period average (LPA) affect the crop much more than flood anomaly. An annual rainfall of $100 \mathrm{~mm}$ below LPA reduces rice yields by $40 \mathrm{~kg} / \mathrm{ha}$, where as an annual rainfall of $100 \mathrm{~mm}$ above LPA reduces yields by $9 \mathrm{~kg} /$ ha $(\operatorname{column}(1))$. Similarly, increases in high temperature anomaly also reduces rice yields, with yields reducing by $157 \mathrm{~kg} /$ ha per degree Celsius increase in temperature above LPA. However, temperatures below LPA are beneficial for crop yields, as is evident from positive and significant coefficient of low temp anomaly. Results for mean yield for rice are qualitatively similar even after standardizing the climate anomalies (column(3)). Coefficients of non climate inputs are positive and significant, as expected. For yield variability, we see that increases in drought anomaly increases rice yield variability, with a rainfall of $100 \mathrm{~mm}$ below LPA increasing rice yield variability by 10 percent. Our results are consistent with those in Arshad et al (2016) who also find rainfall and temperature anomalies to be increasing rice yield variability. However, none of the non climate inputs matter for rice yield variability.

We find similar results for mean yield for sorghum and pearl millet, which are reported 
Table 8: Climate Anomalies determine Mean and Variance of Yields (Rice)

\begin{tabular}{|c|c|c|c|c|c|}
\hline & (1) & (2) & (3) & (4) & (5) \\
\hline $\begin{array}{l}\text { Mean Yield } \\
\text { Drought Anomaly }\end{array}$ & $\begin{array}{l}-4 \mathrm{E}-04^{* * *} \\
(4 \mathrm{E}-05)\end{array}$ & $\begin{array}{l}-4 \mathrm{E}-04^{* * *} \\
(3 \mathrm{E}-05)\end{array}$ & & $\begin{array}{l}-5 \mathrm{E}-04^{* * *} \\
(4 \mathrm{E}-05)\end{array}$ & $\begin{array}{l}-4 \mathrm{E}-04^{* * *} \\
(4 \mathrm{E}-05)\end{array}$ \\
\hline Flood Anomaly & $\begin{array}{l}-9 \mathrm{E}-05^{* * *} \\
(3 \mathrm{E}-05)\end{array}$ & $\begin{array}{l}-\mathrm{E}-04^{* * *} \\
(3 \mathrm{E}-05)\end{array}$ & & $\begin{array}{l}-\mathrm{E}-04^{* * *} \\
(3 \mathrm{E}-05)\end{array}$ & $\begin{array}{l}-\mathrm{E}-04^{* * *} \\
(3 \mathrm{E}-05)\end{array}$ \\
\hline Low Temp Anomaly & $\begin{array}{l}0.075^{* * *} \\
(0.023)\end{array}$ & $\begin{array}{l}0.085^{* * *} \\
(0.021)\end{array}$ & & $\begin{array}{l}0.087^{* * *} \\
(0.023)\end{array}$ & $\begin{array}{l}0.048^{*} \\
(0.025)\end{array}$ \\
\hline High Temp Anomaly & $\begin{array}{l}-0.157^{* * *} \\
(0.024)\end{array}$ & $\begin{array}{l}-0.177^{* * *} \\
(0.020)\end{array}$ & & $\begin{array}{l}-0.184^{* * *} \\
(0.022)\end{array}$ & $\begin{array}{l}-0.142^{* * *} \\
(0.026)\end{array}$ \\
\hline Std Drought Anomaly & & & $\begin{array}{l}-0.054^{* * *} \\
(0.005)\end{array}$ & & \\
\hline Std Flood Anomaly & & & $\begin{array}{l}-0.014^{* * *} \\
(0.005)\end{array}$ & & \\
\hline Std Low Temp Anomaly & & & $\begin{array}{l}0.015^{* * *} \\
(0.005)\end{array}$ & & \\
\hline Std High Temp Anomaly & & & $\begin{array}{l}-0.035^{* * *} \\
(0.006)\end{array}$ & & \\
\hline Area & $\begin{array}{l}0.001 * * * \\
(\mathrm{E}-04)\end{array}$ & & $\begin{array}{l}0.001^{* * *} \\
(\mathrm{E}-04)\end{array}$ & $\begin{array}{l}0.001^{* * *} \\
(\mathrm{E}-04)\end{array}$ & $\begin{array}{l}0.002^{* * *} \\
(\mathrm{E}-04)\end{array}$ \\
\hline Fertilizer & $\begin{array}{l}3.829^{* * *} \\
(0.183)\end{array}$ & & $\begin{array}{l}3.782^{* * *} \\
(0.180)\end{array}$ & $\begin{array}{l}3.451^{* * *} \\
(0.154)\end{array}$ & \\
\hline Irrigation & $\begin{array}{l}0.384^{* * *} \\
(0.051)\end{array}$ & & $\begin{array}{l}0.404^{* * *} \\
(0.050)\end{array}$ & $\begin{array}{l}0.431^{* * *} \\
(0.030)\end{array}$ & $\begin{array}{l}0.430^{* * *} \\
(0.055)\end{array}$ \\
\hline HYV & $\begin{array}{l}0.387^{* * *} \\
(0.025)\end{array}$ & & $\begin{array}{l}0.384^{* * *} \\
(0.024)\end{array}$ & & $\begin{array}{l}0.375^{* * *} \\
(0.027)\end{array}$ \\
\hline$N$ & 5047 & 7513 & 5047 & 6336 & 5090 \\
\hline $\begin{array}{l}\text { Yield Variance } \\
\text { Drought Anomaly }\end{array}$ & $\begin{array}{l}0.001 * * * \\
(3 \mathrm{E}-04)\end{array}$ & $\begin{array}{l}0.001^{* * *} \\
(3 \mathrm{E}-04)\end{array}$ & & $\begin{array}{l}0.001^{* * *} \\
(3 \mathrm{E}-04)\end{array}$ & $\begin{array}{l}0.001^{* *} \\
(3 \mathrm{E}-04)\end{array}$ \\
\hline Flood Anomaly & $\begin{array}{l}2 \mathrm{E}-04 \\
(2 \mathrm{E}-04)\end{array}$ & $\begin{array}{l}-3 \mathrm{E}-04 \\
(2 \mathrm{E}-04)\end{array}$ & & $\begin{array}{l}2 \mathrm{E}-04 \\
(2 \mathrm{E}-04)\end{array}$ & $\begin{array}{l}-3 \mathrm{E}-04 \\
(3 \mathrm{E}-04)\end{array}$ \\
\hline Low Temp Anomaly & $\begin{array}{l}0.162 \\
(0.198)\end{array}$ & $\begin{array}{l}0.139 \\
(0.211)\end{array}$ & & $\begin{array}{l}0.373^{*} \\
(0.195)\end{array}$ & $\begin{array}{l}0.053 \\
(0.196)\end{array}$ \\
\hline High Temp Anomaly & $\begin{array}{l}0.346^{*} \\
(0.198)\end{array}$ & $\begin{array}{l}-0.005 \\
(0.191)\end{array}$ & & $\begin{array}{l}0.152 \\
(0.173)\end{array}$ & $\begin{array}{l}0.330 \\
(0.206)\end{array}$ \\
\hline Std Drought Anomaly & & & $\begin{array}{l}0.133^{* * *} \\
(0.039)\end{array}$ & & \\
\hline Std Flood Anomaly & & & $\begin{array}{l}0.028 \\
(0.040)\end{array}$ & & \\
\hline Std Low Temp Anomaly & & & $\begin{array}{l}0.029 \\
(0.039)\end{array}$ & & \\
\hline Std High Temp Anomaly & & & $\begin{array}{l}0.071 \\
(0.048)\end{array}$ & & \\
\hline Fertilizer & $\begin{array}{l}0.332 \\
(1.505)\end{array}$ & & $\begin{array}{l}0.369 \\
(1.480)\end{array}$ & $\begin{array}{l}-0.866 \\
(1.292)\end{array}$ & \\
\hline Irrigation & $\begin{array}{l}0.763 \\
(0.498)\end{array}$ & & $\begin{array}{l}0.844 \\
(0.440)\end{array}$ & $\begin{array}{l}0.360 \\
(0.332)\end{array}$ & $\begin{array}{l}0.541 \\
(0.441)\end{array}$ \\
\hline HYV & $\begin{array}{l}-0.235 \\
(0.240)\end{array}$ & & $\begin{array}{l}-0.359 \\
(0.227)\end{array}$ & & $\begin{array}{l}-0.333 \\
(0.225)\end{array}$ \\
\hline$N$ & 5047 & 7513 & 5047 & 6336 & 5090 \\
\hline
\end{tabular}


in columns (1)-(5) of Tables 9 and 10. Rainfall extremes reduce mean yield of sorghum and pearl millet, where as increases in high temperature anomaly reduces yield of both crops. Unlike rice, which is a thermal sensitive crop, temperatures below LPA reduce mean yield of sorghum and pearl millet, possibly because millets are grown in high temperature conditions and thus respond negatively to low temperature conditions. Coefficients of non climate inputs are positive and significant across specifications (1)-(5) for both crops. For yield variance regression we find that both low and high temperature anomalies increase sorghum yield variability. For the specifications reported in columns (1), (2), (4), (5) of Table 9, we see that sorghum yield variability increases by $42-52$ percent for a low temp anomaly of 1 degree Celsius. Similarly, yield variability increases by 36-46 percent for a high temp anomaly of 1 degree Celsius. We get similar results with standardized climate anomalies (column(3)). However, coefficient of standardized high temp anomaly is positive but insignificant. Higher drought anomaly continues to increase sorghum yield variability. Among non climate inputs, irrigation expansion and HYV continue to increase sorghum yield variability. Results for variance of pearl millet yields, reported in columns (1)-(5) of Table 10 indicate that increases in flood anomaly increase yield variance, with an annual rainfall of 100 mm above LPA increasing yield variability by 10 percent. Deviations in temperature above LPA increase yield variance, with a high temp anomaly of 1 degree Celsius increasing yield variance by 48-54 percent. Among non climate inputs, irrigation expansion increases yield variance of pearl millet, with an increase in pearl millet irrigated area by 0.10 increasing yield variance by 8-15 percent across specifications reported in columns (1)-(5) of Table 10. Marginal effects of climate variables on mean and variance of crop yields are presented in Table 11. Collectively, these results highlight the importance of climate anomalies in determining both mean crop yields and yield variance. 
Table 9: Climate Anomalies determine Mean and Variance of Yields (Sorghum)

\begin{tabular}{|c|c|c|c|c|c|}
\hline & (1) & $(2)$ & (3) & (4) & $(5)$ \\
\hline $\begin{array}{l}\text { Mean Yield } \\
\text { Drought Anomaly }\end{array}$ & $\begin{array}{l}-4 \mathrm{E}-04^{* * *} \\
(3 \mathrm{E}-05)\end{array}$ & $\begin{array}{l}-4 \mathrm{E}-04^{* * *} \\
(3 \mathrm{E}-05)\end{array}$ & & $\begin{array}{l}-4 \mathrm{E}-04^{* * *} \\
(3 \mathrm{E}-05)\end{array}$ & $\begin{array}{l}-4 \mathrm{E}-04^{* * *} \\
(3 \mathrm{E}-05)\end{array}$ \\
\hline Flood Anomaly & $\begin{array}{l}-2 \mathrm{E}-04^{* * *} \\
(2 \mathrm{E}-05)\end{array}$ & $\begin{array}{l}-2 \mathrm{E}-04^{* * *} \\
(2 \mathrm{E}-05)\end{array}$ & & $\begin{array}{l}-2 \mathrm{E}-04^{* * *} \\
(2 \mathrm{E}-05)\end{array}$ & $\begin{array}{l}-2 \mathrm{E}-04^{* * *} \\
(2 \mathrm{E}-05)\end{array}$ \\
\hline Low Temp Anomaly & $\begin{array}{l}0.051^{* * *} \\
(0.015)\end{array}$ & $\begin{array}{l}-0.041^{* * *} \\
(0.014)\end{array}$ & & $\begin{array}{l}-0.049^{* * *} \\
(0.015)\end{array}$ & $\begin{array}{l}-0.050^{* * *} \\
(0.015)\end{array}$ \\
\hline High Temp Anomaly & $\begin{array}{l}-0.114^{* * *} \\
(0.016)\end{array}$ & $\begin{array}{l}-0.056^{* * *} \\
(0.014)\end{array}$ & & $\begin{array}{l}-0.113^{* * *} \\
(0.016)\end{array}$ & $\begin{array}{l}-0.115^{* * *} \\
(0.016)\end{array}$ \\
\hline Std Drought Anomaly & & & $\begin{array}{l}-0.039^{* * *} \\
(0.004)\end{array}$ & & \\
\hline Std Flood Anomaly & & & $\begin{array}{l}-0.026^{* * *} \\
(0.004)\end{array}$ & & \\
\hline Std Low Temp Anomaly & & & $\begin{array}{l}-0.011^{* * *} \\
(0.003)\end{array}$ & & \\
\hline Std High Temp Anomaly & & & $\begin{array}{l}-0.032^{* * *} \\
(0.004)\end{array}$ & & \\
\hline Area & $\begin{array}{l}3 \mathrm{E}-04^{* * *} \\
(9 \mathrm{E}-05)\end{array}$ & & $\begin{array}{l}3 \mathrm{E}-04^{* * *} \\
(9 \mathrm{E}-05)\end{array}$ & $\begin{array}{l}3 \mathrm{E}-04^{* * *} \\
(9 \mathrm{E}-05)\end{array}$ & $\begin{array}{l}2 \mathrm{E}-04^{* * *} \\
(9 \mathrm{E}-05)\end{array}$ \\
\hline Fertilizer & $\begin{array}{l}0.517^{* * *} \\
(0.125)\end{array}$ & & $\begin{array}{l}0.531^{* * *} \\
(0.125)\end{array}$ & $\begin{array}{l}0.502^{* * *} \\
(0.127)\end{array}$ & \\
\hline Irrigation & $\begin{array}{l}0.486^{* * *} \\
(0.091)\end{array}$ & & $\begin{array}{l}0.486^{* * *} \\
(0.091)\end{array}$ & $\begin{array}{l}0.492^{* * *} \\
(0.091)\end{array}$ & $\begin{array}{l}0.478^{* * *} \\
(0.090)\end{array}$ \\
\hline HYV & $\begin{array}{l}0.115^{* * *} \\
(0.016)\end{array}$ & & $\begin{array}{l}0.113^{* * *} \\
(0.016)\end{array}$ & & $\begin{array}{l}0.118^{* * *} \\
(0.016)\end{array}$ \\
\hline$N$ & 4485 & 5488 & 4485 & 4485 & 4485 \\
\hline $\begin{array}{l}\text { Yield Variance } \\
\text { Drought Anomaly }\end{array}$ & $\begin{array}{l}4 \mathrm{E}-04 \\
(4 \mathrm{E}-04)\end{array}$ & $\begin{array}{l}0.001^{* * *} \\
(4 \mathrm{E}-04)\end{array}$ & & $\begin{array}{l}4 \mathrm{E}-04 \\
(4 \mathrm{E}-04)\end{array}$ & $\begin{array}{l}0.001 \\
(4 \mathrm{E}-04)\end{array}$ \\
\hline Flood Anomaly & $\begin{array}{l}-2 \mathrm{E}-04 \\
(3 \mathrm{E}-04)\end{array}$ & $\begin{array}{l}2 \mathrm{E}-04 \\
(3 \mathrm{E}-04)\end{array}$ & & $\begin{array}{l}-2 \mathrm{E}-04 \\
(3 \mathrm{E}-04)\end{array}$ & $\begin{array}{l}-\mathrm{E}-04 \\
(3 \mathrm{E}-04)\end{array}$ \\
\hline Low Temp Anomaly & $\begin{array}{l}0.516^{* * *} \\
(0.203)\end{array}$ & $\begin{array}{l}0.427^{* *} \\
(0.191)\end{array}$ & & $\begin{array}{l}0.505^{* *} \\
(0.203)\end{array}$ & $\begin{array}{l}0.499^{* *} \\
(0.207)\end{array}$ \\
\hline High Temp Anomaly & $\begin{array}{l}0.460^{* *} \\
(0.197)\end{array}$ & $\begin{array}{l}0.357^{* *} \\
(0.164)\end{array}$ & & $\begin{array}{l}0.450^{* *} \\
(0.196)\end{array}$ & $\begin{array}{l}0.414^{* *} \\
(0.198)\end{array}$ \\
\hline Std Drought Anomaly & & & $\begin{array}{l}0.078^{*} \\
(0.042)\end{array}$ & & \\
\hline Std Flood Anomaly & & & $\begin{array}{l}-0.038 \\
(0.421)\end{array}$ & & \\
\hline Std Low Temp Anomaly & & & $\begin{array}{l}0.103^{* *} \\
(0.043)\end{array}$ & & \\
\hline Std High Temp Anomaly & & & $\begin{array}{l}0.074 \\
(0.057)\end{array}$ & & \\
\hline Fertilizer & $\begin{array}{l}0.459 \\
(1.415)\end{array}$ & & $\begin{array}{l}0.543 \\
(1.503)\end{array}$ & $\begin{array}{l}0.623 \\
(1.404)\end{array}$ & \\
\hline Irrigation & $\begin{array}{l}1.667^{* *} \\
(0.675)\end{array}$ & & $\begin{array}{l}1.709^{* * *} \\
(0.655)\end{array}$ & $\begin{array}{l}1.704^{* *} \\
(0.680)\end{array}$ & $\begin{array}{l}1.727^{* *} \\
(0.693)\end{array}$ \\
\hline HYV & $\begin{array}{l}0.420^{* *} \\
(0.187)\end{array}$ & & $\begin{array}{l}0.453 \\
(0.180)\end{array}$ & & $\begin{array}{l}0.429^{* *} \\
(0.183)\end{array}$ \\
\hline$N$ & 4485 & 5488 & 4485 & 4485 & 4485 \\
\hline
\end{tabular}


Table 10: Climate Anomalies determine Mean and Variance of Yields (Pearl Millet)

\begin{tabular}{|c|c|c|c|c|c|}
\hline & (1) & $(2)$ & (3) & (4) & $(5)$ \\
\hline $\begin{array}{l}\text { Mean Yield } \\
\text { Drought Anomaly }\end{array}$ & $\begin{array}{l}-0.001^{* * *} \\
(4 \mathrm{E}-05)\end{array}$ & $\begin{array}{l}-0.001^{* * *} \\
(4 \mathrm{E}-05)\end{array}$ & & $\begin{array}{l}-0.001 * * * \\
(4 \mathrm{E}-05)\end{array}$ & $\begin{array}{l}-0.001 * * * \\
(4 \mathrm{E}-05)\end{array}$ \\
\hline Flood Anomaly & $\begin{array}{l}-2 \mathrm{E}-04^{* * *} \\
(3 \mathrm{E}-05)\end{array}$ & $\begin{array}{l}-2 \mathrm{E}-04^{* * *} \\
(3 \mathrm{E}-05)\end{array}$ & & $\begin{array}{l}-2 \mathrm{E}-04^{* * *} \\
(3 \mathrm{E}-05)\end{array}$ & $\begin{array}{l}-\mathrm{E}-04^{* * *} \\
(3 \mathrm{E}-05)\end{array}$ \\
\hline Low Temp Anomaly & $\begin{array}{l}-0.037^{* *} \\
(0.017)\end{array}$ & $\begin{array}{l}-0.014 \\
(0.018)\end{array}$ & & $\begin{array}{l}-0.037^{* *} \\
(0.017)\end{array}$ & $\begin{array}{l}-0.035^{* *} \\
(0.017)\end{array}$ \\
\hline High Temp Anomaly & $\begin{array}{l}-0.112^{* * *} \\
(0.019)\end{array}$ & $\begin{array}{l}-0.105^{* * *} \\
(0.019)\end{array}$ & & $\begin{array}{l}-0.112^{* * *} \\
(0.019)\end{array}$ & $\begin{array}{l}-0.118^{* * *} \\
(0.019)\end{array}$ \\
\hline Std Drought Anomaly & & & $\begin{array}{l}-0.059^{* * *} \\
(0.004)\end{array}$ & & \\
\hline Std Flood Anomaly & & & $\begin{array}{l}-0.023^{* * *} \\
(0.005)\end{array}$ & & \\
\hline Std Low Temp Anomaly & & & $\begin{array}{l}-0.009^{* * *} \\
(0.004)\end{array}$ & & \\
\hline Std High Temp Anomaly & & & $\begin{array}{l}-0.030^{* * *} \\
(0.006)\end{array}$ & & \\
\hline Area & $\begin{array}{l}0.001^{* * *} \\
(\mathrm{E}-04)\end{array}$ & & $\begin{array}{l}0.001^{* * *} \\
(\mathrm{E}-04)\end{array}$ & $\begin{array}{l}0.001^{* * *} \\
(\mathrm{E}-04)\end{array}$ & $\begin{array}{l}0.001^{* * *} \\
(\mathrm{E}-04)\end{array}$ \\
\hline Fertilizer & $\begin{array}{l}1.343^{* * *} \\
(0.177)\end{array}$ & & $\begin{array}{l}1.325^{* * *} \\
(0.173)\end{array}$ & $\begin{array}{l}1.339^{* * *} \\
(0.174)\end{array}$ & \\
\hline Irrigation & $\begin{array}{l}0.553^{* * *} \\
(0.058)\end{array}$ & & $\begin{array}{l}0.519^{* * *} \\
(0.059)\end{array}$ & $\begin{array}{l}0.501^{* * *} \\
(0.059)\end{array}$ & $\begin{array}{l}0.451^{* * *} \\
(0.059)\end{array}$ \\
\hline HYV & $\begin{array}{l}0.049^{* * *} \\
(0.018)\end{array}$ & & $\begin{array}{l}0.055^{* * *} \\
(0.018)\end{array}$ & & $\begin{array}{l}0.062^{* * *} \\
(0.017)\end{array}$ \\
\hline$N$ & 3466 & 4266 & 3466 & 3466 & 3466 \\
\hline $\begin{array}{l}\text { Yield Variance } \\
\text { Drought Anomaly }\end{array}$ & $\begin{array}{l}-6 \mathrm{E}-05 \\
(5 \mathrm{E}-04)\end{array}$ & $\begin{array}{l}-3 \mathrm{E}-05 \\
(5 \mathrm{E}-04)\end{array}$ & & $\begin{array}{l}-9 \mathrm{E}-05 \\
(5 \mathrm{E}-04)\end{array}$ & $\begin{array}{l}3 \mathrm{E}-05 \\
(5 \mathrm{E}-04)\end{array}$ \\
\hline Flood Anomaly & $\begin{array}{l}0.001 \\
(4 \mathrm{E}-04)\end{array}$ & $\begin{array}{l}0.001^{* *} \\
(3 \mathrm{E}-04)\end{array}$ & & $\begin{array}{l}0.001 \\
(4 \mathrm{E}-04)\end{array}$ & $\begin{array}{l}3 \mathrm{E}-04 \\
(4 \mathrm{E}-04)\end{array}$ \\
\hline Low Temp Anomaly & $\begin{array}{l}-0.110 \\
(0.259)\end{array}$ & $\begin{array}{l}0.105 \\
(0.255)\end{array}$ & & $\begin{array}{l}-0.108 \\
(0.259)\end{array}$ & $\begin{array}{l}-0.035 \\
(0.254)\end{array}$ \\
\hline High Temp Anomaly & $\begin{array}{l}0.480^{* *} \\
(0.247)\end{array}$ & $\begin{array}{l}0.544^{* *} \\
(0.226)\end{array}$ & & $\begin{array}{l}0.482^{* *} \\
(0.247)\end{array}$ & $\begin{array}{l}0.527^{* *} \\
(0.241)\end{array}$ \\
\hline Std Drought Anomaly & & & $\begin{array}{l}-0.027 \\
(0.053)\end{array}$ & & \\
\hline Std Flood Anomaly & & & $\begin{array}{l}0.105^{*} \\
(0.055)\end{array}$ & & \\
\hline Std Low Temp Anomaly & & & $\begin{array}{l}-0.044 \\
(0.055)\end{array}$ & & \\
\hline Std High Temp Anomaly & & & $\begin{array}{l}0.198^{* * *} \\
(0.073)\end{array}$ & & \\
\hline Fertilizer & $\begin{array}{l}-1.054 \\
(2.101)\end{array}$ & & $\begin{array}{l}0.607 \\
(2.126)\end{array}$ & $\begin{array}{l}-1.054 \\
(2.108)\end{array}$ & \\
\hline Irrigation & $\begin{array}{l}1.018^{* *} \\
(0.472)\end{array}$ & & $\begin{array}{l}0.820^{*} \\
(0.460)\end{array}$ & $\begin{array}{l}1.002^{* *} \\
(0.475)\end{array}$ & $\begin{array}{l}1.540^{* * *} \\
(0.506)\end{array}$ \\
\hline HYV & $\begin{array}{l}-0.103 \\
(0.187)\end{array}$ & & $\begin{array}{l}-0.038 \\
(0.191)\end{array}$ & & $\begin{array}{l}-0.111 \\
(0.189)\end{array}$ \\
\hline$N$ & 3466 & 4266 & 3466 & 3466 & 3466 \\
\hline
\end{tabular}




\section{Concluding Remarks}

We investigate the impact of climate extremes on mean yields and yield variability for three major food grains grown in our country, namely, rice, sorghum and pearl millet using the stochastic production function approach formulated by Just and Pope $(1978,1979)$. Rising temperature affects average crop yields adversely, the impact is highest for rice. This is consistent with findings from other studies (Peng et al. 2004). Our results confirm the importance of rainfall in agricultural production. Use of other agricultural inputs such as fertilizer, irrigation and high yielding variety seeds also increases average crop yields, which is consistent with other studies controlling for irrigation coverage, fertilizer use and use of high yielding variety seeds (Pattanayak and Kumar 2014; Auffhammer, Ramanathan, and Vincent 2012). Acreage expansion, on the other hand, increases crop yields, though marginally. We find that increased climate variability, climate extremes in particular, increase production risk. Rice yield variability is particularly sensitive to fluctuations in rainfall with high temperature anomalies increasing millet yield variability. As the econometric results could be subject to omitted variable bias, we leave it for further research to employ a richer set of mean and variability shifters than employed in this paper. The analysis presented in this study has important policy implications. Rising global population puts enormous pressure on existing natural resources requiring stable agricultural production which is crucial not only for food security, but has serious welfare implications. There has been a steep increase in farmer suicides due to farm distress owing to climate related losses in agricultural production. Low global food stock in conjunction with fluctuations in agricultural production, can contribute to food price spikes (Piesse and Thirtle 2009). In turn, this poses a serious threat to food security and increasing vulnerability of poor rural farmers, especially in the arid and semiarid tropics (Bates, Kundzewicz, and Wu 2008). Further, variability in agricultural production translates into variability in farm incomes which discourages farmers to undertake productive investments in this sector. To mitigate the effects of climate change, genetically modified crop varieties have been introduced in many countries such as BtCorn 
in Philippines. Sanglestsawai et al. (2017) find that the use of such crops increases farmer's welfare because of the dual advantage of increasing average crop yields and reducing production risk, where risk is measured by skewness of the distribution of crop yields. Research findings from our study highlight the need to undertake suitable policy measures to make Indian agriculture resilient to climate change. 


\section{References}

Anderson, Jock R. and P. B. R. Hazell. 1989. Variability in grain yields: Implications for agricultural research and policy in developing countries. International Food Policy Research Institute.

Anderson, Jock R. and P. B. R. Hazell. 1989. Variability in grain yields: Implications for agricultural research and policy in developing countries. Published for the International Food Policy Research Institute, The Johns Hopkins University Press, Baltimore and London.

Arguez, Anthony, and Russell S Vose. 2011. "The definition of the standard WMO climate normal: The key to deriving alternative climate normals." Bulletin of the American Meteorological Society 92 (6):699-704.

Arshad, Muhammad et al. 2016. "Climate variability and yield risk in South Asia's rice-wheat systems: Emerging evidence from Pakistan." Paddy and Water Environment 15 (2): 249-261.

Arumugam, Surendran, Suren N Kulshreshtha, Isaac Vellangany, and Ramu Govindasamy. 2015. "Yield variability in rainfed crops as influenced by climate variables: A micro

level investigation into agro-climatic zones of Tamil Nadu, India." International Journal of Climate Change Strategies and Management 7 (4): 442-459.

Auffhammer, Maximilian, Veerabhadran Ramanathan, and Jeffrey R Vincent. 2012. "Climate change, the monsoon, and rice yield in India." Climatic Change 111 (2): 411-424.

Barnabas, Beata, Katalin Jager, and Attila Feher. 2008. "The effect of drought and heat stress on reproductive processes in cereals." Plant, Cell and Environment 31 (1): 11-38.

Barnwal, Prabhat and Koji Kotani. 2010. "Impact of variation in climatic factors on crop yield: A case of rice crop in Andhra Pradesh, India." Economics and Management Series, Working Paper, IUJ Research Institute, International University of Japan.

Basavaraj, G, P Parthasarathy Rao, Shraavya Bhagavatula, and Wasim Ahmed. 2010. "Availability and utilization of pearl millet in India." SAT eJournal, vol. 8.

Bates, Bryson, Zbigniew Kundzewicz, and Shaohong Wu. 2008. Climate change and 
Water. Intergovernmental Panel on Climate Change Secretariat.

Blanc, Elodie, and Wolfram Schlenker. 2017. "The use of panel models in assessments of climate impacts on agriculture." Review of Environmental Economics and Policy 11 (2): $258-279$.

Boubacar, Inoussa. 2012. "The effects of drought on crop yields and yield variability: An economic assessment." International Journal of Economics and Finance 4(12): 51-60.

Cabas, Juan, Alfons Weersink, and Edward Olale. 2010. "Crop yield response to economic, site and climatic variables." Climatic Change 101 (3-4): 599-616.

Cagliarini, Adam, Anthony Rush, et al. 2011. "Economic development and agriculture in India." RBA Bulletin, June, pp. 15-22.

Call, Maia, Clark Gray, and Pamela Jagger. 2019. "Smallholder responses to climate anomalies in rural Uganda." World Development 115:132-144.

Chand, Ramesh. 2007. "Demand for foodgrains." Economic and Political Weekly, pp. $10-13$.

Chang, Ching-Cheng. 2002. "The potential impact of climate change on Taiwan's agriculture." Agricultural Economics 27(1): 51-64.

Chen, Chi-Chung, Bruce A McCarl, and David E Schimmelpfennig. 2004. "Yield variability as influenced by climate: A statistical investigation." Climatic Change 66 (1-2): 239261.

Chen, Chi-Chung, and Ching-Cheng Chang. 2005. "The impact of weather on crop yield distribution in Taiwan: some new evidence from panel data models and implications for crop insurance." Agricultural Economics 33: 503-511.

Collier, Michael, and Robert H Webb. 2002. Floods, Droughts, and Climate Change. University of Arizona Press.

Di Falco, S., J. P. Chavas, and M. Smale. 2006. "Farmer Management of Production Risk on Degraded Lands: The Role of Wheat Genetic Diversity in Tigray Region, Ethiopia." Environmental and Production Technology Division. Discussion Paper 153 IFPRI, Washington DC, USA. 
Gilmont, M, et al. 2018. "Analysis of the relationship between rainfall and economic growth in Indian states." Global Environmental Change 49:56-72.

Government of India (GoI). 2010. "Indian Network for Climate Change Assessment." Ministry of Environment and Forests, New Delhi.

Government of India (GoI). 2016a. "Annual Climate Summary - 2016." Ministry of Earth Sciences.

Government of India (GoI). 2016b. "Pocket Book of Agricultural Statistics 2016." Ministry of Agriculture and Farmers Welfare.

Government of India (GoI). 2018. "Annual Climate Summary - 2018." Ministry of Earth Sciences.

Guttormsen, A. G., and K. H. Roll. 2013. "Production risk in a subsistence agriculture." Journal of Agricultural Education and Extension 20(1): 133-145.

Haile, Mekbib G, Tesfamicheal Wossen, Kindie Tesfaye, and Joachim von Braun. 2017. "Impact of climate change, weather extremes, and price risk on global food supply." Economics of Disasters and Climate Change 1 (1): 55-75.

Hasanthika, WKAMA, JC Edirisinghe, and RDDP Rajapakshe. 2013. "Climate Variability, Risk and Paddy Production." Journal of Environmental Professionals Sri Lanka 2 (2): 57-65.

Holst, Rainer, Xiaohua Yu, and Carola Grun. 2013. "Climate change, risk and grain yields in China." Journal of Integrative Agriculture 12 (7): 1279-1291.

Hoogenboom, Gerrit. 2000. "Contribution of agrometeorology to the simulation of crop production and its applications." Agricultural and Forest Meteorology 103(1-2): 137-157.

ICRISAT-ICAR-IRRI. 2015 (accessed November 28, 2015). Macro-Meso Apportioned Database. Retrieved from http://vdsa.icrisat.ac.in/Include/Document/ all-apportioned-webdocument.pdf.

Intergovernmental Panel on Climate Change (IPCC). 2014. Climate Change 2014: Synthesis Report. Contribution of Working Groups I, II and III to the Fifth Assessment Report of the Intergovernmental Panel on Climate Change, Cambridge University Press. 
Isik, Murat, and Stephen Devadoss. 2006. "An analysis of the impact of climate change on crop yields and yield variability." Applied Economics 38(7): 835-844.

Just, Richard E, and Rulon D Pope. 1978. "Stochastic specification of production functions and economic implications." Journal of Econometrics 7 (1): 67-86.

Just, Richard E, and Rulon D Pope. 1979. "Production function estimation and related risk considerations." American Journal of Agricultural Economics 61 (2): 276-284.

Kabir, H. et al. 2015. "Impacts of climate change on rice Yield and variability; an analysis of disaggregate level in the southwestern part of Bangladesh especially Jessore and Sathkhira districts." Scholarly Journal of Agricultural Science 5 (8): 283-295.

Kadiyala, Suneetha et al. 2014. "Agriculture and nutrition in India: Mapping evidence to pathways." Annals of the New York Academy of Sciences 1331 (1): 43-56.

Kim, Man-Keun, and Arwin Pang. 2009. "Climate change impact on rice yield and production risk." Journal of Rural Development 32(2): 17-29.

Kumar, Ajay, Pritee Sharma, and Sunil Kumar Ambrammal. 2015. "Climatic effects on sugarcane productivity in India: a stochastic production function application." International Journal of Economics and Business Research 10 (2): 179-203.

Mahmood, Nasir, et al. 2019. "Wheat yield response to input and socioeconomic factors under changing climate: Evidence from rainfed environments of Pakistan." Science of the Total Environment 688:1275-1285.

McCarl, Bruce A, Xavier Villavicencio, and Ximing Wu. 2008. "Climate change and future analysis: Is stationarity dying?" American Journal of Agricultural Economics 90 (5): 1241-1247.

Mearns, Linda O., Cynthia Rosenzweig, and Richard Goldberg. 1997. "Mean and variance change in climate scenarios: methods, agricultural applications, and measures of uncertainty." Climatic Change 35 (4): 367-396.

Millet Network of India (MNI). 2009 (accessed August 29, 2009). Millets: future of food and farming. Retrieved from http://www. swaraj.org/shikshantar/millets.pdf.

Nagaraj, N, G Basavaraj, P Parthasarathy Rao, Cynthia Bantilan, and Surajit Haldar. 
2013. "Sorghum and pearl millet economy of India: Future outlook and options." Economic and Political Weekly, pp. 74-81.

Naidu, CV, et al. 2009. "Is summer monsoon rainfall decreasing over India in the global warming era?" Journal of Geophysical Research: Atmospheres 114 (D24): 1-16.

Palanisami, K., C. R. Ranganathan, K. R. Kakumanu, and Udaya Sekhar Nagothu. 2011. "A Hybrid model to quantify the impact of climate change on agriculture in Godavari basin, India." Energy and Environment Research 1(1): 32-52.

Pattanayak, Anubhab, and KS Kavi Kumar. 2014. "Weather sensitivity of rice yield: Evidence from India." Climate Change Economics 5 (04): 1450011.

Peng, Shaobing, et al. 2004. "Rice yields decline with higher night temperature from global warming." Proceedings of the National Academy of Sciences 101 (27): 9971-9975.

Piesse, Jenifer, and Colin Thirtle. 2009. "Three bubbles and a panic: An explanatory review of recent food commodity price events." Food Policy 34 (2): 119-129.

Poudel, Santosh, and Koji Kotani. 2013. "Climatic impacts on crop yield and its variability in Nepal: Do they vary across seasons and altitudes?" Climatic Change 116 (2): 327- 355 .

Poudel, Mahadeb Prasad, Shwu-En Chen, and Wen-Chi Huang. 2014. "Climate influence on rice, maize and wheat yields and yield variability in Nepal." Journal of Agricultural Science and Technology B 4 (1B): 38-48.

Rajeevan, M, Jyoti Bhate, JD Kale, and B Lal. 2005. "Development of a high resolution daily gridded rainfall data for the Indian region." Meteorological Monograph Climatology No. 22:2005.

Ramaswami, Bharat. 1992. "Production risk and optimal input decisions." American Journal of Agricultural Economics 74(4): 860-869.

Ranuzzi, Anna, and Richa Srivastava. 2012. "Impact of climate change on agriculture and food security in India." Working Paper No. 16 Indian Council for Research on International Economic Relations (ICRIER), New Delhi.

Rao, P Parthasarathy, et al. 2006. "Diagnostics of sorghum and pearl millet grains-based 
nutrition in India." International Sorghum and Millets Newsletter 47:93-96.

Rao, P Parthasarathy, and AJ Hall. 2003. "Importance of crop residues in crop-livestock systems in India and farmers perceptions of fodder quality in coarse cereals." Field Crops Research 84 (1-2): 189-198.

Rohini, P, M Rajeevan, and AK Srivastava. 2016. "On the variability and increasing trends of heat waves over India." Scientific Reports 6:26153.

Rosegrant, Mark W., and James A. Roumasset. 1985. "The effect of fertiliser on risk: a heteroscedastic production function with measurable stochastic inputs." Australian Journal of Agricultural Economics 29(2): 107-121.

Roumasset, J. A. et al. 1989. "Fertilizer and crop yield variability: A review." Variability in Grain Yields: 223-233.

Saei, Mahdiyeh, Hamid Mohammadi, Saman Ziaee, and Sajad Barkhordari. 2019. "The Impact of Climate Change on Grain Yield and Yield Variability in Iran." Iranian Economic Review 23(2): 509-531.

Sanglestsawai, Santi, Divina Gracia P Rodriguez, Roderick M Rejesus, and Jose M Yorobe. 2017. "Production Risk, Farmer Welfare, and Bt Corn in the Philippines." Agricultural and Resource Economics Review 46 (3): 507-528.

Sarker, Md Abdur Rashid, Khorshed Alam, and Jeff Gow. 2014. "Assessing the effects of climate change on rice yields: An econometric investigation using Bangladeshi panel data." Economic Analysis and Policy 44 (4): 405-416.

Sarker, Md Abdur Rashid, Khorshed Alam, and Jeff Gow. 2017. "Performance of rainfed Aman rice yield in Bangladesh in the presence of climate change." Renewable Agriculture and Food Systems 34(4) : 304-312.

Schlenker, Wolfram, and Michael J. Roberts. 2009. "Nonlinear temperature effects indicate severe damages to US crop yields under climate change." Proceedings of the National Academy of Sciences 106(37): 15594-15598.

Sen Roy, Shouraseni, and Robert C Balling Jr. 2004. "Trends in extreme daily precipitation indices in India." International Journal of Climatology: A Journal of the Royal 
Meteorological Society 24 (4): 457-466.

Singh, Ajay, Kumar, Pritee, Sharma and Durgesh Kumar Singh. 2016. "Measuring the influence of weather variables on productivity of food-grain crops in India: An application of Just Pope's production technique." ABBS Management Business and Entrepreneurship Review, 7(2): 29-46.

Srivastava, AK, M Rajeevan, and SR Kshirsagar. 2009. "Development of a high resolution daily gridded temperature data set (1969-2005) for the Indian region." Atmospheric Science Letters 10 (4): 249-254.

Swaminaidu, N, et al. 2015. "Millets: The miracle grain." International Journal of Pharma and Bio Sciences 6 (4): 440-446.

Torriani, Daniele, et al. 2007. "Regional assessment of climate change impacts on maize productivity and associated production risk in Switzerland." Regional Environmental Change 7(4): 209-221.

Wooldridge, Jeffrey M. 2012. "Econometric Analysis of Cross Section and Panel Data." Massachusetts Institute of Technology, United States of America.

Xiong, Wei, Declan Conway, Ian Holman, and Erda Lin. 2008. "Evaluation of CERESWheat simulation of wheat production in China." Agronomy Journal 100(6): 1720-1728. 


\section{Appendix}

\section{A Tables and Figures}

Table A.1: Unit root tests results

\begin{tabular}{lccc}
\hline \hline Variable & Rice & Sorghum & Pearl Millet \\
\hline Phillips Perron test & & \\
Rainfall & $-60.18^{* * *}$ & $-54.89^{* * *}$ & $-45.52^{* * *}$ \\
Temperature & $-56.40^{* * *}$ & $-47.79^{* * *}$ & $-39.91^{* * *}$ \\
Yield & $-41.19^{* * *}$ & $-39.31^{* * *}$ & $-42.62^{* * *}$ \\
Area & $-28.62^{* * *}$ & $-14.83^{* * *}$ & $-33.61^{* * *}$ \\
Fertilizer & $-16.06^{* * *}$ & $-15.14^{* * *}$ & $-13.74^{* * *}$ \\
Irrigation & $-26.39^{* * *}$ & $-11.34^{* * *}$ & $-25.39^{* * *}$ \\
HYV & $-6.83^{* * *}$ & $-14.21^{* * *}$ & $-10.61^{* * *}$ \\
\hline $\begin{array}{l}\text { Im Pesaran Shin (IPS) test } \\
\text { Rainfall }\end{array}$ & $-55.37^{* * *}$ & $-51.30^{* * *}$ & $-44.41^{* * *}$ \\
Temperature & $-51.00^{* * *}$ & $-42.58^{* * *}$ & $-39.98^{* * *}$ \\
Yield & $-26.82^{* * *}$ & $-28.80^{* * *}$ & $-33.07^{* * *}$ \\
Area & $-20.91^{* * *}$ & $-9.46^{* * *}$ & $-26.08^{* * *}$ \\
Fertilizer & $-8.60^{* * *}$ & $-9.81^{* * *}$ & $-8.65^{* * *}$ \\
Irrigation & -2 & 11.27 & $-20.18^{* * *}$ \\
HYV & 0.89 & $-8.78^{* * *}$ & $-9.21^{* * *}$ \\
\hline \hline $\begin{array}{l}\text { Notes: Cross sectional averages have been } \\
\text { is included in the estimated equation. }\end{array}$ & & \\
*** indicates 1\% significance level. & & \\
Combining the test results, null hypothesis of non stationarity \\
a WtBar statistic not computed due to insufficient observations. \\
\end{tabular}


Table A.2: Mundlak test results

\begin{tabular}{|c|c|c|c|}
\hline Variable & Rice & Sorghum & Pearl Millet \\
\hline Wald $\mathrm{Chi}^{2}$ & $96.20^{* * *}$ & $62.49^{* * *}$ & $224.63^{* * *}$ \\
\hline $\begin{array}{l}\text { Notes: } * * * \\
\text { Coefficient } \\
\text { are robust } \\
\text { Null hypot } \\
\text { time invari } \\
\text { is rejected }\end{array}$ & $\begin{array}{l}\text { ndicates } \\
\text { stimates } \\
\text { heterosc } \\
\text { esis of no } \\
\text { nt unobse } \\
\text { ith } 99 \%\end{array}$ & $\begin{array}{l}\text { o significar } \\
\text { the estim } \\
\text { dasticity. } \\
\text { orrelation } \\
\text { ables and } \\
\text { nfidence. }\end{array}$ & $\begin{array}{l}\text { ee level. } \\
\text { ted equation } \\
\text { etween } \\
\text { egressors }\end{array}$ \\
\hline
\end{tabular}


Figure A.1: India-rainfall and agricultural production

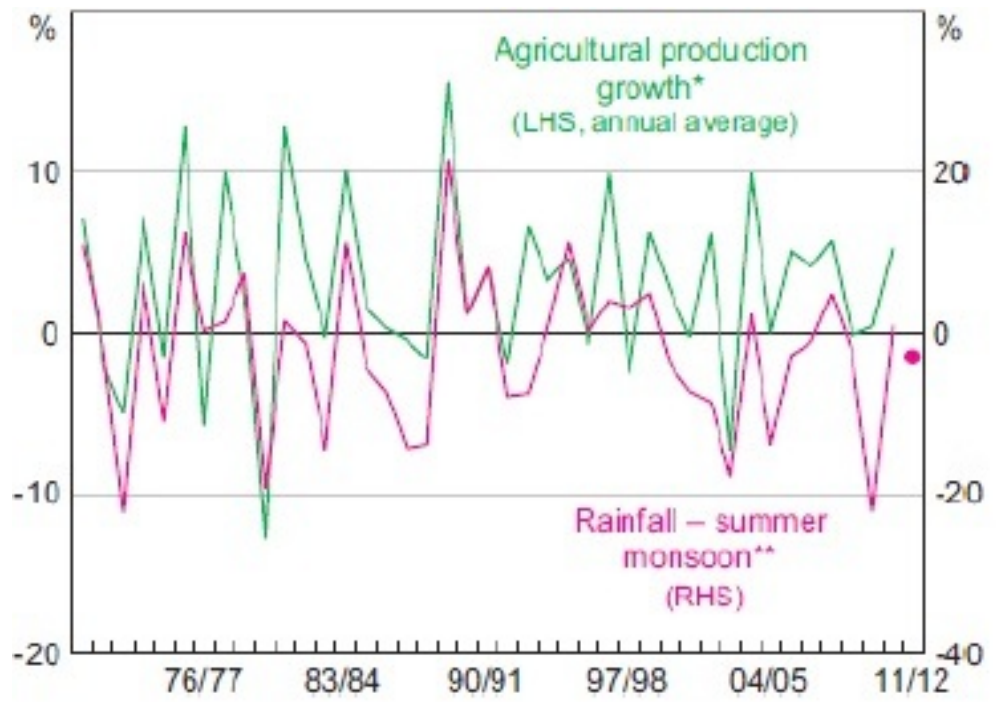

**Percentage deviation from long-run average.

Source: Cagliarini and Rush (2011) 
Figure A.2: Crop Yield (tons/hectare)

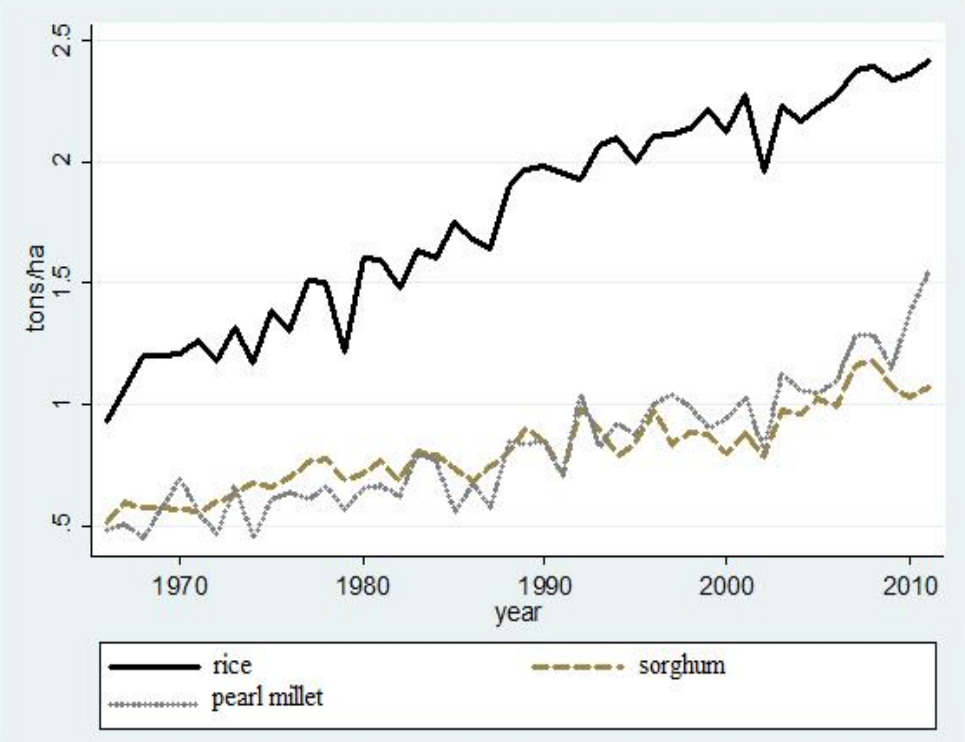


Figure A.3: Annual Rainfall (mm)

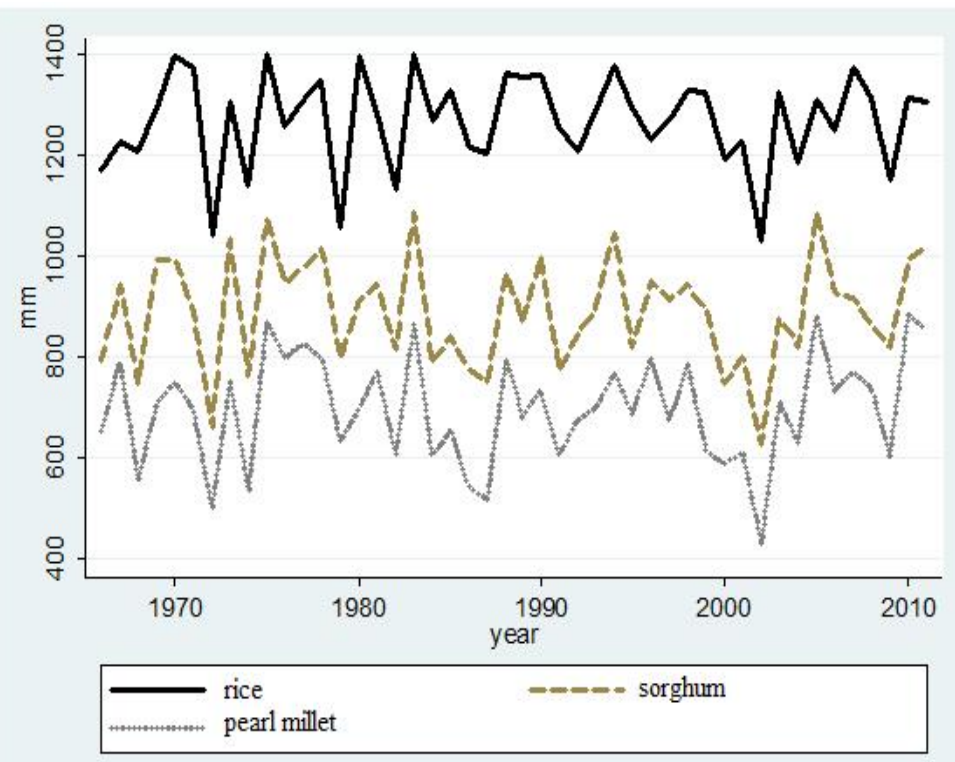


Figure A.4: Annual Average Temperature $\left({ }^{\circ} \mathrm{C}\right)$

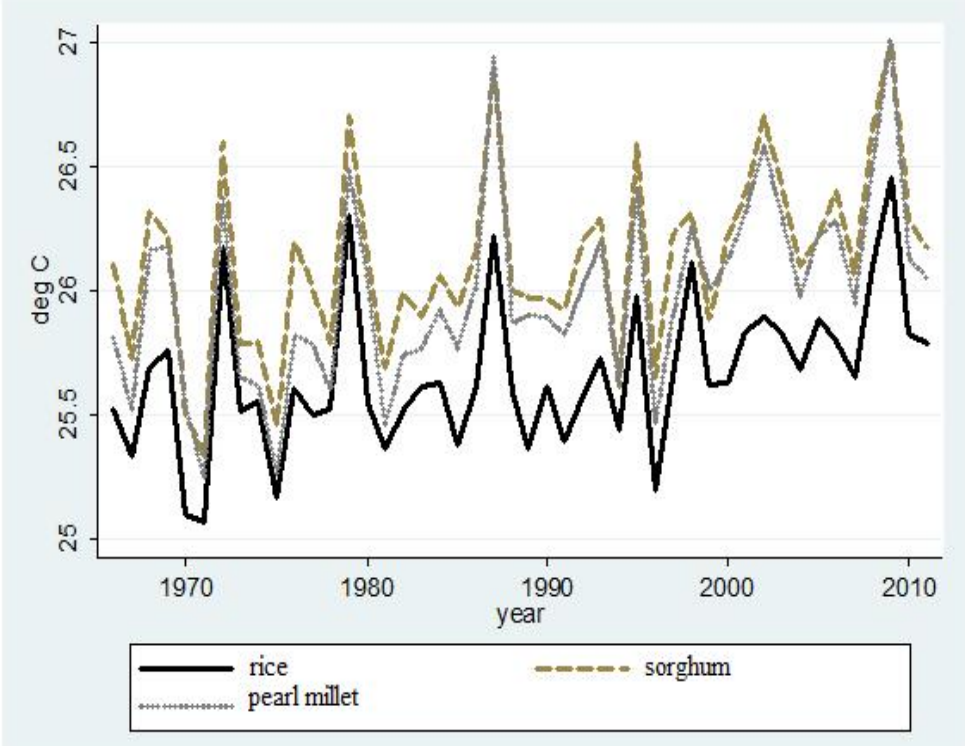


Figure A.5: All India Rainfall Anomaly (\%)

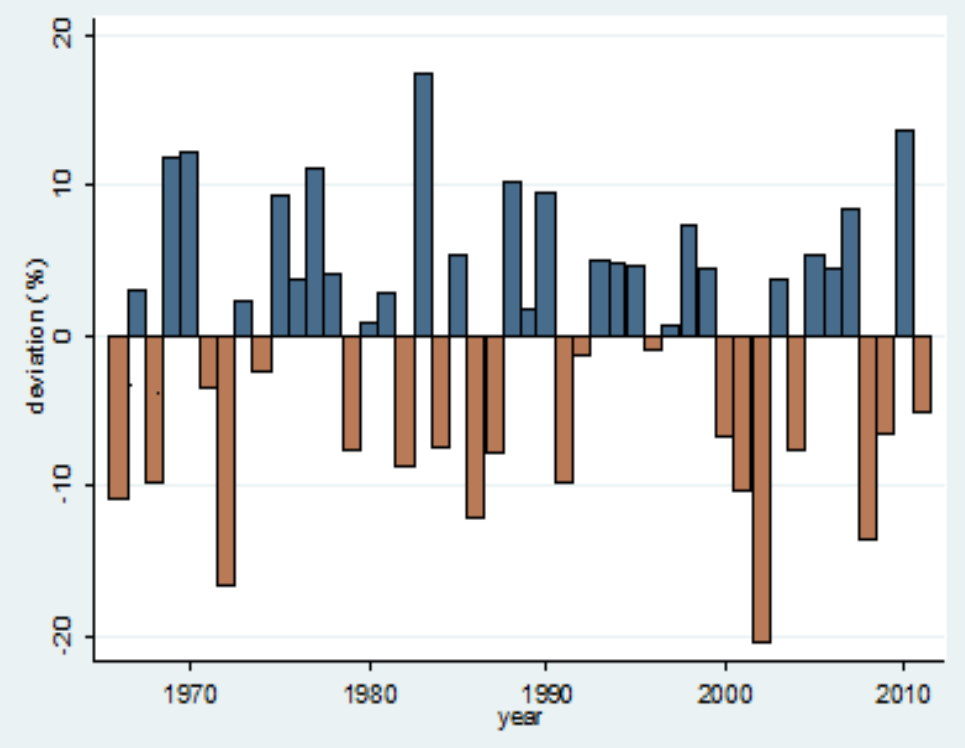


Figure A.6: All India Temperature Anomaly (\%)

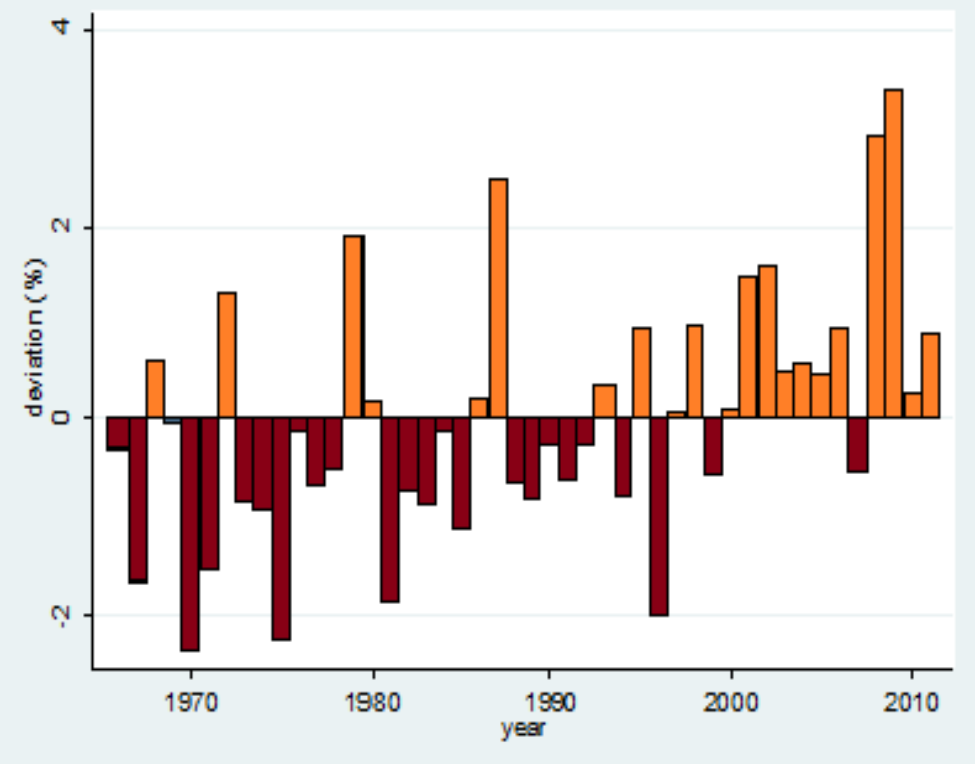




\section{B List of Districts}

\section{Rice (163 districts)}

Andhra Pradesh : Adilabad, Anantapur, Chittoor, Cuddapah, East Godavari, Guntur,

Karimnagar, Khammam, Krishna, Kurnool, Mahabubnagar, Medak, Nalgonda, Nellore,

Nizamabad, Srikakulum, Visakhapatnam, Warangal, West Godavari

Assam : Cachar, Darrang, Dibrugarh, Goalpara, Kamrup, Karbi Anglong, Lakhimpur

Bihar : Bhagalpur, Champaran, Darbhanga,Gaya, Hazaribagh, Monghyr, Muzaffarpur, Palamau,

Patna, Purnea, Ranchi, Saharsa, Santhal Paragana, Saran, Shahabad, Singhbhum

Gujarat : Ahmedabad, Bulsar, Kaira, Surat

Haryana : Ambala, Hissar,Jind, Karnal, Rohtak

Karnataka : Bellary, Chickmagalur, Chitradurga, Dakshina Kannara, Uttara Kannara,

Dharwad, Hassan, Mandya, Mysore, Raichur, Shimoga

Kerala : Alapuzha, Eranakulam, Palakkad, Thrisur

Madhya Pradesh : Balaghat, Bastar, Bilaspur, Durg, Raigarh, Raipur, Seoni, Shahdol, Surguja

Maharashtra : Bhandara, Chandrapur, Kolhapur, Raigad, Ratnagiri,Thane

Orissa : Balasore, Bolangir, Cuttack, Dhenkanal, Ganjam, Kalahandi, Keonjhar, Koraput,

Mayurbhanj, Phulbani, Puri, Sambalpur, Sundergarh

Punjab : Amritsar, Bhatinda, Ferozpur, Gurdaspur, Hoshiarpur, Jalandhar, Kapurthala,

Ludhiana, Patiala, Roopnagar, Sangrur

Tamil Nadu : Chengalpattu, Coimbatore, Madurai, North Arcot, Ramanthapuram, Salem,

South Arcot, Thanjavur, Tiruchirapalli, Tirunelveli, Kanyakumari

Uttar Pradesh : Allahabad, Azamgarh, Bahraich, Ballia, Barabanki, Bareilly, Basti, Bijnor,

Deoria, Etawah, Faizabad, Fatehpur, Ghazipur, Gonda, Gorakhpur, Hardoi, Jaunpur, Kanpur,

Kheri, Mainpuri, Mirzapur, Moradabad, Nainital, Pilibhit, Pratapgarh, Rae Bareily, Rampur,

Saharanpur, Shahjahanpur, Sitapur, Sultanpur, Unnao, Varanasi

West Bengal : Bankura, Birbhum, Burdwan,Cooch-Behar, Hooghly, Howrah, Jalpaiguri, Malda,

Midnapore, Murshidabad, Nadia, Purulia, Twenty Four Paraganas, West Dinajpur 


\section{Sorghum (121 districts)}

Andhra Pradesh : Adilabad, Anantapur, Cuddapah, Guntur, Hyderabad, Karimnagar,

Khammam, Krishna, Kurnool, Mahabubnagar, Medak, Nalgonda, Nellore, Nizamabad, Warangal

Gujarat : Ahmedabad, Amreli, Banaskantha, Baroda, Bhavnagar, Broach, Junagadh, Mehsana, Rajkot, Surat, Surendranagar

Haryana : Rohtak

Karnataka : Belgaum, Bellary, Bidar, Bijapur, Chickmagalur, Chitradurga, Dharwad, Gulbarga, Hassan, Mysore, Raichur, Shimoga, Tumkur

Madhya Pradesh : Betul, Bhind, Chhatarpur, Chhindwara, Damoh, Dewas, Dhar, Guna, Gwalior, Hoshangabad, Indore, Jabalpur, Jhabua, Khandwa, Khargone, Mandsaur, Morena, Narsinghpur, Rajgarh, Ratlam, Rewa, Sagar, Sehore, Shajapur, Shivpuri, Sidhi, Tikamgarh, Ujjain, Vidisha

Maharashtra : Ahmednagar, Akola, Amravati, Aurangabad, Beed, Buldhana, Chandrapur,

Dhulia, Jalgaon, Kolhapur, Nagpur, Nanded, Nasik, Osmanabad, Parbhani, Pune, Sangli, Satara, Solapur, Wardha, Yeotmal

Rajasthan : Ajmer, Alwar, Bharatpur, Bhilwara, Bundi, Chittorgarh, Jaipur, Jhalawar, Kota, Nagaur, Pali, Sawai Madhopur, Tonk

Tamil Nadu : Coimbatore, Madurai, South Arcot, North Arcot, Ramanathapuram, Salem, Tiruchirapalli, Tirunelveli

Uttar Pradesh : Allahabad, Banda, Fatehpur, Hamirpur, Hardoi, Jalaun, Jhansi, Kanpur, Rae Bareily, Unnao 


\section{Pearl Millet (94 districts)}

Andhra Pradesh :Anantapur, Chittoor, Cuddapah, Guntur, Kurnool, Mahabubnagar,

Nalgonda, Nellore, Visakhapatnam

Gujarat : Ahmedabad, Amreli, Banaskantha, Baroda, Bhavnagar, Jamnagar, Junagadh, Kaira, Kutch, Mehsana, Panch Mahals, Rajkot, Sabarkantha, Surendranagar

Haryana : Gurgaon, Hissar, Jind, Karnal, Mahendragarh, Rohtak

Karnataka: Belgaum, Bellary, Bijapur, Gulbarga, Raichur

Madhya Pradesh : Bhind, Morena

Maharashtra : Ahmednagar, Aurangabad, Beed, Dhulia, Jalgaon, Nasik, Osmanabad, Pune, Sangli, Satara, Solapur

Punjab : Bhatinda, Ferozpur, Sangrur

Rajasthan : Ajmer, Alwar, Barmer, Bharatpur, Bikaner, Churu, Ganganagar, Jaipur, Jaisalmer, Jalore, Jhunjhunu, Jodhpur, Nagaur, Pali, Sawai Madhopur, Sikar, Tonk

Tamil Nadu : South Arcot, North Arcot, Salem, Coimbatore, Tiruchirapalli, Madhurai, Ramanathapuram, Tirunelveli, Vellore

Uttar Pradesh : Agra, Aligarh, Allahabad, Bareilly, Buduan, Bulandshahar, Etah, Etawah, Farrukhabad, Ghazipur, Jalaun, Kanpur, Mainpuri, Mathura, Mirzapur, Moradabad, Pratapgarh, Varanasi 